\title{
Argumenty na rzecz naturalizmu jako epistemicznego układu odniesienia
}

\section{Uwagi wstępne}

Epistemiczne układy odniesienia (EUO) nauki to przyjmowane na mocy decyzji uczonych niewielkie (dwu- lub trzyelementowe) zbiory najogólniejszych, historycznie zmiennych założeń. Te ostatnie określają konieczne warunki uprawiania nauki. ${ }^{1}$ Inaczej to wyrażając, EUO to najbardziej elementarne założenia

\footnotetext{
Dr hab. Krzysztof J. Kilian, prof. UZ - Uniwersytet Zielonogórski, e-mail: kiliankrzysztof @yahoo.pl.

(C) Copyright by Krzysztof J. Kilian \& Filozoficzne Aspekty Genezy.

${ }^{1}$ Nazwa „epistemiczny układ odniesienia” została wprowadzona przez Kazimierza Jodkow skiego w referacie „Epistemiczne układy odniesienia i «warunek Jodkowskiego»” na konferencji „Filozoficzne i naukowo-przyrodnicze elementy obrazu świata” (UKSW, 01.12.2004) (por. Zenon E. RoskaL, „Eksperyment MacDougalla w epistemicznym układzie odniesienia naturalizmu”, w: Piotr Bylica, Krzysztof J. Kilian, Robert Piotrowski i Dariusz Sagan (red.), Filozofia — nauka — religia. Księga jubileuszowa dedykowana Profesorowi Kazimierzowi Jodkowskiemu z okazji 40-lecia pracy naukowej, Oficyna Wydawnicza Uniwersytetu Zielonogórskiego, Zielona Góra 2015, s. 166 przyp. 6 [165-172], http://tiny.pl/g28sj [15.10.2018]; Kazimierz JoDKowsKi, „Epistemiczne układy odniesienia i «warunek Jodkowskiego»", w: Anna Latawiec i Grzegorz BugaJaK (red.), Filozoficzne i naukowo-przyrodnicze elementy obrazu świata 7, Wydawnictwo Uniwersytetu Kardynała Stefana Wyszyńskiego, Warszawa 2008, s. 115 [108-123], http://tiny.pl/g28sn [15.10.2018]).

Analizy epistemicznych układów odniesienia przedstawiłem w następujących artykułach: „Geneza idei epistemicznych układów odniesienia i ich odmiany”, Filozoficzne Aspekty Genezy 2017, t. 14, s. 137-190, https://tiny.pl/gzx34 (08.10.2018); „Czym są epistemiczne układy odniesienia?", Filozoficzne Aspekty Genezy 2017, t. 14, s. 191-236, https://tiny.pl/g8xqp (08.10.2018); „Epistemiczne układy odniesienia a problem interteoretycznej niewspółmierności - część 1”, Filozoficzne Aspekty Genezy 2017, t. 14, s. 237-280, https://tiny.pl/gzx3s (08.10.2018); „Epistemiczne układy odniesienia a problem interteoretycznej niewspółmierności - część 2", Filozo-
} 
dotyczące tego, jak należy uprawiać naukę i jak tego robić nie należy. Wskazują one, co według danej grupy uczonych jest w praktyce naukowej zakazane, a co nie. Wyznaczają tym samym zakres dopuszczalnych rozwiązań problemów. Pośrednio informują też o tym, co istnieje, dzięki czemu kreślą również najogólniejszą perspektywę metafizyczną uprawiania nauki. ${ }^{2}$

Idea EUO jest rozszerzeniem idei uteoretyzowania obserwacji. Jeśli nie ma nagich faktów i wszystkie fakty zinterpretowane są w jakiejś ramie teoretycznej, to nie ma też „nagiej nauki”. Ta ostatnia zawsze uprawiana jest w jakimś uprzednio zaakceptowanym kontekście. ${ }^{3}$ Koncepcja EUO wiąże się z, nie w pełni jeszcze akceptowaną i rozpoznawaną, tezą o nieredukowalnej obecności filozofii w nauce ${ }^{4}$ oraz z odrzuceniem ideału bezzałożeniowości. Odrzucenie to łączy się z przyjęciem tezy o założeniowości, zgodnie z którą nauka nie może funkcjonować bez założeń filozoficznych. ${ }^{5}$

Ta ostatnia teza ma trzy składowe. ${ }^{6}$ Zgodnie z pierwszą nauka jako całość przyjmuje wstępne założenia dotyczące natury badanej rzeczywistości i sposo-

ficzne Aspekty Genezy 2017, t. 14, s. 281-325, https://tiny.pl/gzx3v (08.10.2018).

${ }^{2}$ Por. np. Kazimierz Jodkowski, „Nienaukowy fundament nauki”, w: Zbigniew PIEtRzAK (red.), Granice nauki, Lectiones \& Acroases Philosophicae 2013, vol. 6, nr 1, s. 100-105 [59108], http://tiny.pl/q3mlq (15.10.2018).

${ }^{3}$ Por. np. wypowiedź Kazimierza Jodkowskiego w: Piotr Bylica, Kazimierz Jodkowski, Krzysztof J. KILIAN i Dariusz SAGAN, „Dyskusja nad artykułem Adama Groblera, «Słabości eksplanacyjne teorii inteligentnego projektu»", Filozoficzne Aspekty Genezy 2013, t. 10, s. 53 [17-63], https://tiny.pl/q3m1m (15.10.2018). Por. też Piotr ByLICA, Współczesny teizm naturalistyczny z punktu widzenia modelu poziomów analizy. Problem dzialania sfery nadnaturalnej w przyrodzie, Biblioteka Filozoficznych Aspektów Genezy, t. 7, Instytut Filozofii Uniwersytetu Zielonogórskiego, Zielona Góra 2016, s. 26, http://tiny.pl/gkdv1 (16.10.2018).

${ }^{4}$ Por. np. Kazimierz JoDKowski, „Metafizyczne opowieści nauki jako fundament pluralizmu naukowego", w: Phillip E. Johnson, Wielka metafizyczna opowieść nauki (z posłowiem Kazimierza Jodkowskiego), przeł. Piotr Bylica, Archiwum Na Poczatku..., z. 13, Polskie Towarzystwo Kreacjonistyczne, Warszawa 2003, s. 80-81 [74-85], http://tiny.pl/q3m5p (18.10.2018); KILIAN, „Geneza epistemicznych układów...”, s. 139-142.

${ }^{5}$ Por. Kazimierz Jodkowski, „Curriculum Vitae”, http://tiny.pl/gkfxf (18.10.2018). Por. też Joachim Metallmann, „Nauka, pogląd na świat, filozofia”, odbitka z Przegladu Współczesnego 1939, nr 5-7, s. 29-30 [1-49], https://tiny.pl/gzn7n (18.10.2018).

${ }^{6}$ Por. KiLIan, „Geneza epistemicznych układów...”, s. 141-142. 
bów badania tej ostatniej. ${ }^{7} \mathrm{~W}$ myśl drugiej w ramach nauki istnieje możliwość rewizji jej podstawowych założeń. Naukę można uprawiać w różnych EUO. ${ }^{8}$ Wedle trzeciej składowej w poznaniu naukowym występują nieusuwalne, lecz zmienne, metafizyczne komponenty teorii naukowych. Komponenty te można dość dowolnie zmieniać. Nie da się ich jednak całkowicie wyeliminować. ${ }^{9}$

Jedynym powszechnie znanym i dobrze opisanym w filozofii EUO jest naturalizm metodologiczny. Składają się nań trzy, wywodzące się od Karola Darwina, decyzje. Pierwsza z nich nakazuje przyjmowanie jedynie naturalistycznych wyjaśnień dla faktów, procesów i zjawisk. ${ }^{10}$ Decyzję tę uzupełnił Darwin dwoma innymi, wykluczającymi wyjaśnienia antynaturalistyczne. Są to zakazy przyjmowania wyjaśnień powołujących się na przyczyny nadnaturalne ${ }^{11}$ i celowe. ${ }^{12} \mathrm{~W}$ takiej postaci naturalizm ten jest nakazem ograniczania badań do świata przyrody, a co za tym idzie nakazem przyjmowania jedynie naturalistycznych wyjaśnień dla faktów i procesów, wraz z jednoczesnym zakazem przyjmowania wyjaśnień antynaturalistycznych. Ten ostatni zakaz, na co należy zwrócić uwagę, dotyczy dwóch różnych typów wyjaśnień: z jednej strony powołujących się

\footnotetext{
${ }^{7}$ Por. Kazimierz JodKowski, „Uczony w ciemnym budynku. Na marginesie metafory Elżbiety Kałuszyńskiej”, w: Józef Dębowski i Ewa StarzyŃsKa-Kościuszko (red.), Nauka. Racjonalność. Realizm. Między filozofią przyrody a filozofią nauki i socjologią wiedzy, Instytut Filozofii Uniwersytetu Warmińsko-Mazurskiego w Olsztynie, Olsztyn 2013, s. 57 [55-67], https://tiny.pl/q3m 1x (18.10.2018); wypowiedź Jodkowskiego w: Bylica, Jodkowski, Kilian i SAGAN, „Dyskusja nad artykułem Adama Groblera...", s. 51.

${ }^{8}$ Por. Jodkowski, „Nienaukowy fundament...”, s. 105

${ }^{9}$ Por. np. Kazimierz Jodkowski, „Przedmowa”, Filozoficzne Aspekty Genezy 2004, t. 1, s. 5-6 [5-6], http://tiny.pl/g8kn6 (02.10.2018); Piotr BylicA, „Kazimierza Jodkowskiego koncepcja epistemicznych układów odniesienia a teizm naturalistyczny Johna Polkinghorne'a”, w: ByLICA, KILian, Piotrowski i Sagan (red.), Filozofia — nauka - religia..., s. 192-193 [191-211], http://tiny. $\mathrm{pl} / \mathrm{g} 8 \mathrm{~h} 4 \mathrm{z}(18.10 .2018)$.

${ }^{10}$ Por. Karol DARwin, O powstawaniu gatunków drogą doboru naturalnego, czyli o utrzymaniu się doskonalszych ras w walce o byt. Dzieła wybrane, t. 2, przeł. Szymon Dickstein i Józef Nusbaum, Państwowe Wydawnictwo Rolnicze i Leśne, Warszawa 1959, s. 386.

${ }^{11}$ Por. Darwin, O powstawaniu gatunków..., s. 386.

${ }^{12}$ Por. Karol DARwin, Autobiografia i wybór listów. Dzieła wybrane, t. 8, przeł. A. Iwanowska, A. Krasicka, J. Połtowicz i S. Skowron, Państwowe Wydawnictwo Rolnicze i Leśne, War szawa 1960, s. 44. Por. też Grzegorz Malec, „Teologiczne dylematy Karola Darwina”, Roczniki Filozoficzne 2012, t. 60, nr 1, s. 69-70 [67-85], http://tiny.p1/g4751 (13.10.2018).
} 
na przyczyny nadnaturalne (antynaturalizm ${ }_{1}$ ), zaś z drugiej - na inteligentne (antynaturalizm $)_{2}$.

Jak powszechnie wiadomo, współcześnie osią sporu o charakter dopuszczalnych wyjaśnień są nauki o życiu. Dlatego to naturalistyczne kryterium sformułowano przede wszystkim dla tych nauk. ${ }^{13}$ Powszechna akceptacja takiego szerokiego kryterium, akcentującego rozszerzenie wymogów naturalizmu metodologicznego o decyzję zakazującą dopuszczania wyjaśnień artyficjalistycznych, doprowadziła do istotnych problemów natury teoretycznej. Zaproponowano zespół decyzji, które są niezgodne z tym, co na co dzień robi się w nauce. Prowadzą one do uznania za nienaukowe tych dyscyplin, którym powszechnie nie odmawia się statusu naukowości. Istnieją bowiem dyscypliny (na przykład archeologia), które dopuszczają wyjaśnienia artyficjalistyczne (archeologowie niejednokrotnie stwierdzają, że odkryte przez nich przedmioty są wytworami istot inteligentnych), a nikt im nie odmawia pretensji do naukowości:

Skoro w innych naukach, tak humanistycznych, jak i przyrodniczych, dopuszcza się poszukiwanie i odnajdywanie śladów rozumnej aktywności, to nie ma pozaideologicznych powodów, by zabronić tego samego biologom. ${ }^{14}$

W myśl kreślonego tu ujęcia współcześnie funkcjonują cztery EUO, które układają się w następujące pary:

naturalizm antynadnaturalistyczny — nadnaturalizm (antynaturalizm 1 );

naturalizm antyartyficjalistyczny - artyficjalizm (antynaturalizm 2 ). ${ }^{15}$

\footnotetext{
${ }^{13}$ Por. np. Francisco J. Ayala, „Darwin's Revolution”, w: John H. Campbell and J.W. Schoff (eds.), Creative Evolution!?, Jones and Bartlett, New York 1994, s. 4-5 [1-18].

${ }^{14}$ Kazimierz Jodкоwsкi, „Rozpoznawanie genezy: istota sporu ewolucjonizm-kreacjonizm”, Roczniki Filozoficzne 2002, t. 50, z. 3, s. 194 [187-198], http://tiny.pl/xh2bp (11.10.2018) [wyróżnienie dodane].

${ }^{15}$ Por. Kazimierz Jodkowski, „Antynaturalizm teorii inteligentnego projektu”, Roczniki Filozoficzne 2006, t. 54, nr 2, s. $72-73$ [63-76], http://tiny.pl/qzq86 (12.10.2018); KiLIAN, „Geneza epistemicznych układów...”, s. 139.

Argumenty za i przeciw artyficjalizmowi obszernie omawia Dariusz SAGAN, „Teoria inteligentnego projektu - argumenty za i przeciw”, w: Stanisław JaneczeK, Anna Starościc, Dariusz DABEK i Justyna Herda (red.), Filozofia przyrody, Dydaktyka Filozofii, t. III, Wydawnictwo Katolickiego Uniwersytetu Lubelskiego, Lublin 2013, s. 339-371 [335-383], https://tiny.pl/q336w (13. 10.2018).
} 
Decyzje konstytuujące wymogi naturalizmu metodologicznego, jak będę się starał pokazać, nie opierają się ani na faktach, ani też nie są efektem nieodpartych rozumowań. Innymi słowy, ani fakty, ani rozumowania nie stanowią nieodpartych racji na korzyść naturalizmu metodologicznego.

$\mathrm{Na}$ rzecz tego naturalizmu sformułowano wiele argumentów. Przedstawione w dwóch następnych paragrafach omówienie nie pretenduje do zupełności. Jednakże argumenty tam przedstawione, jako efekt przeglądu reprezentatywnej dla podejmowanej tu problematyki literatury, ${ }^{16}$ rzucają wyraźne światło na omawiane zagadnienie. Omawiane argumenty podzielone zostaną ze względu na to, czy $\mathrm{w}$ ich ramach nie są dopuszczalne rewizje naturalizmu metodologicznego (część 2), czy też są (część 3). Następnie podzielone zostaną ze względu na to, czy zawierają konkretne warunki utrzymywania naturalizmu albo jego porzucenia, czy też takich warunków nie podają.

\section{Argumenty na rzecz niedopuszczania rewizji naturalizmu metodologicznego}

W ramach podejścia, które nie dopuszcza rewizji naturalizmu metodologicznego, pojawiają się następujące grupy argumentów: (a) „nie, bo nie”; (b) w imię zasady uporczywości należy obstawać przy naturalizmie; (c) naturalizm jest definicyjnym składnikiem pojęcia nauki; (d) naturalizm tworzy skuteczną tradycję uprawiania nauki; (e) naturalizm zagwarantować ma środowisku naukowemu największy z możliwych konsensus; (f) naturalizm jest formą brzytwy Ockhama; (g) dopuszczenie wyjaśnień nienaturalistycznych ma szkodliwe następstwa dla uprawiania nauki. Omówię je teraz kolejno.

(a) Argumenty „nie, bo nie” nie zawierają żadnych prób przekonania do przedstawianej propozycji. Przykładem takiego argumentu jest twierdzenie,

\footnotetext{
${ }^{16}$ Zebrane tutaj argumenty pochodzą $\mathrm{z}$ różnych tekstów. Niektóre bronią naturalizmu metodologicznego, inne z nim polemizują, a jeszcze inne go jedynie omawiają. W związku z tym nie zawsze jest tak, że przytaczany autor jest obrońcą podejścia naturalistycznego. Artykuł ten korzysta z osiągnięć Zielonogórskiej Grupy Lokalnej „Nauka a Religia”. Mam tu na myśli przede wszystkim Serwis Filozoficzny „Nauka a Religia”, czasopismo internetowe Filozoficzne Aspekty Genezy, serię książkową Biblioteka Filozoficznych Aspektów Genezy oraz prace członków ZGL publikowane $\mathrm{w}$ innych czasopismach i seriach książkowych.
} 
zgodnie z którym „dla zasady” ${ }^{17}$ uczeni powinni odrzucać wyjaśnienia nienaturalistyczne. Twierdzeniu temu bardzo łatwo można przeciwstawić inne:

nauka pozbawiona dyskusji staje się propagandą. ${ }^{18}$

Nauka, która twierdzi, że posiada jedynie słuszną metodę oraz niepodważalne wyniki, jest ideologią i musi być oddzielona od państwa, a zwłaszcza od kształcenia. ${ }^{19}$

(b) Przy naturalizmie obstawać należy nawet w obliczu możliwych miażdżących niepowodzeń wyjaśnień naturalistycznych:

Może nadejdzie dzień, w którym jednoznacznie zawiodą wszystkie sensowne eksperymenty chemiczne przeprowadzone w celu odkrycia prawdopodobnego scenariusza powstania życia. Ponadto nowe świadectwo geologiczne może wskazać na nagłe pojawienie się życia na Ziemi. W końcu być może dokonamy eksploracji Wszechświata, nie znajdując nigdzie żadnego śladu życia albo procesu prowadzącego do jego powstania. W takim przypadku niektórzy naukowcy mogliby poszukać odpowiedzi w religii. Inni jednak, łącznie ze mną, spróbowaliby zbadać pozostałe mniej prawdopodobne wyjaśnienia naukowe w nadziei wybrania jednego, które będzie bardziej prawdopodobne od innych. ${ }^{20}$

Nietrudno tu dostrzec Feyerabendowską zasadę uporczywości, która zaleca by z wielu teorii wybrać tę, która ma najbardziej atrakcyjne cechy oraz obiecuje

\footnotetext{
${ }^{17}$ Por. Franklin M. Harold, The Way of the Cell: Molecules, Organisms, and the Order of Life, Oxford University Press, Oxford 2001, s. 205.

${ }^{18}$ John G. Hartnett, ,The Problem with Science Is That So Much of It Simply Isn't”, Journal of Creation 2017, vol. 13, no. 2, s. 7 [6-7].

${ }^{19}$ Paul K. Feyerabend, „Mit «Nauki» i jego rola w społeczeństwie”, przeł. Janusz Jusiak, w: Kazimierz JodKowski (red.), Czy sprzeczność może być racjonalna?, Realizm. Racjonalność. Relatywizm, t. 4, Wydawnictwo UMCS, Lublin 1986, s. 300 [292-307], https://tiny.pl/gz5b1 (18.10. 2018).

${ }^{20}$ Robert SHAPIro, Origins. A Skeptic's Guide to the Creation of Life on Earth, Toronto 1987, s. 130 (cyt. za: Dariusz SAGAN, „Naturalizm metodologiczny a zagadnienie prawdy w nauce", w: Andrzej L. Zachariasz (red.), Poznanie a prawda, Wydawnictwo Uniwersytetu Rzeszowskiego, Rzeszów 2009, s. 172-173 [167-173], https://tiny.pl/q33sv [18.10.2018]). Por też Scott C. Todd, „A View from Kansas on That Evolution Debate”, Nature 1999, no. 6752, s. 423, https://tiny.pl/gz5bs (18.10.2018); Thomas NAGEL, „Public Education and Intelligent Design”, Philosophy \& Public Affairs 2008, vol. 36, no. 2, s. 193 [209-219], https://tiny.pl/gz5b3 (18.10. 2018).
} 
prowadzić do najbardziej owocnych wyników i obstawać przy niej, nawet jeśli jest niezgodna $\mathrm{z}$ doświadczeniem lub napotyka na inne znaczące trudności. ${ }^{21}$

Feyerabend, co warto w tym miejscu podkreślić, zalecał kontrolę zasady uporczywości za pomocą zasady proliferacji. (W myśl tej drugiej należy wymyślać alternatywne punkty widzenia nawet $\mathrm{w}$ sytuacji, gdy dominująca teoria jest dobrze potwierdzona i nic nie wskazuje na to, że należy z niej zrezygnować.) Tylko wtedy, jego zdaniem, można w pełni wykorzystać zalety tej pierwszej. Pisał tak:

Tego typu rozważania [biorące pod uwagę zarówno to, że każda teoria może zostać ulepszona, jak i to, że jej związek z doświadczeniem może być różnie oceniany w świetle na przykład dokładniejszych technik eksperymentalnych] zmuszają nas do przyjęcia zasady uporczywości, która proponuje, po pierwsze, aby wybierać z wielu teorii tę jedną, która ma najbardziej atrakcyjne cechy, i która daje nadzieję na najbardziej owocne wyniki, i, po drugie, aby obstawać przy tej teorii mimo znaczących trudności. Po zaakceptowaniu zasady uporczywości, teoria $T$ nie może już być usunięta przez niezgodne z nią eksperymenty. Należy wyznaczyć granicę niezgody, poza którą nie jest się gotowym wyjść. Nie jest łatwo określić, w jaki niearbitralny sposób granica taka może zostać ustalona. Najbardziej przytłaczające trudności mogą zostać przezwyciężone, a mniejsze zakłócenia mieć fatalne konsekwencje (porównaj początkowe trudności teorii heliocentrycznej $\mathrm{z}$ początkowym nastawieniem do eksperymentu Michelsona i Morleya). Lecz jest racjonalne wycofanie $T$, jeśli istnieje inna teoria $T$, która podkreśla trudności $T$ (i która jest zatem z $T$ niezgodna) i jednocześnie daje nadzieję na ich usunięcie i otwiera nowe drogi badań. W takim wypadku sama zasada uporczywości nakłania nas do pozbycia się $T$. Taka metoda refutacji, oczywiście, działa jedynie wtedy, gdy dozwolone jest branie pod uwagę teorii niezgodnych z $T$; alternatyw względem $T$. Wynikiem tego jest to, że nauka, która gotowa jest na rozwijanie swoich teorii pomimo trudności, potrzebuje zasady proliferacji do celów skutecznej krytyki uporczywie utrzymywanych teorii. ${ }^{22}$

\footnotetext{
${ }^{21}$ Por. Paul K. Feyerabend, „Ku pocieszeniu specjalisty”, w: Paul K. Feyerabend, Jak być dobrym empirystą, przeł. Krystyna Zamiara, Państwowe Wydawnictwo Naukowe, Warszawa 1979, s. 208 [200-250]. Por. też Kazimierz Jodкоwski, „Radykalna epistemologia”, Studia Filozoficzne 1984, nr 11-12, s. 182 [179-187], https://tiny.pl/gz5z1 (18.10.2018); Krzysztof J. KILIAN, „Proliferacja jako narzędzie podtrzymujące ewolucję człowieka w świetle poglądów Paula K. Feyerabenda z okresu umiarkowanego", Filozoficzne Aspekty Genezy 2013, t. 13, s. 180-189 [179-202], https://tiny.pl/xhzd3 (18.10.2018).

${ }^{22}$ Paul K. Feyerabend, „Outline of a Pluralistic Theory of Knowledge and Action”, w: Paul K. Feyerabend, Philosophical Papers. Vol. 3. Knowledge, Science and Relativism, Cambridge University Press, Cambridge 1999, s. 107-108 [104-111]. Por. też Krzysztof J. KiLıan, Poglądy filozoficzne Paula K. Feyerabenda. Część I. Program metodologiczny, Oficyna Wydawnicza
} 
Zasada uporczywości, którą zaleca omawiany argument, przekształci się w dogmat, gdy nigdy nie dopuści możliwości akceptacji alternatywnego punktu widzenia, czyli wtedy, gdy nie będzie wspierana zasadą proliferacji.

(c) Na rzecz naturalizmu metodologicznego jako definicyjnego składnika pojęcia nauki argumentowano rozmaicie.

$\left(\mathrm{c}_{1}\right)$ Naturalizm metodologiczny jest podstawowym założeniem nauki współczesnej, z którego nie może ona zrezygnować, ${ }^{23}$ gdyż wyjaśnienia nienaturalistyczne są nietestowalne. ${ }^{24}$

Są do pomyślenia testy, które mogłyby podważyć wyjaśnienia artyficjalistyczne i nadnaturalistyczne. Przykładowo, jeśli kreacjoniści utrzymują, że życie nie mogło powstać w sposób naturalny, to laboratoryjnie przeprowadzony proces syntezy życia uznany powinien być za argument przeciwko nadnaturalizmowi. ${ }^{25}$

Dla wyjaśnień artyficjalistycznych również sformułowano kryterium, na mocy którego można od nich odstąpić. Wystarczy podać kontrprzykład dla tezy: nie istnieje naturalna przyczyna, która jest w stanie wytworzyć nieredukowalną lub wyspecyfikowaną złożoność. ${ }^{26}$ Wnioskowanie o inteligentnej przyczynie na

Uniwersytetu Zielonogórskiego, Zielona Góra 2014, s. 271-274.

${ }^{23}$ Por. Arthur N. Strahler, Understanding Science: An Introduction to Concepts and Issues, Buffalo, New York 1992, s. 3.

${ }^{24}$ Por. Robert T. Pennock, Tower of Babel: The Evidence against the New Creationism, MIT Press, Cambridge 1999, s. 194-196.

${ }^{25}$ Por. Kazimierz JoDKowsKi, Metodologiczne aspekty kontrowersji ewolucjonizm-kreacjonizm, Realizm. Racjonalność. Relatywizm, t. 35, Wydawnictwo UMCS, Lublin 1998, s. 257-266.

${ }^{26}$ Pojęcie nieredukowalnej złożoności wprowadził Michael Behe:

Definiuję układ nieredukowalnie złożony jako pojedynczy system złożony z poszczególnych dobrze dopasowanych, oddziałujących ze sobą części, które mają udział w pełnieniu podstawowej funkcji układu. Usunięcie jakiejkolwiek z tych części powoduje, że system przestaje sprawnie funkcjonować.

Michael J. BeHE, „Nieredukowalna złożoność: problem dla ewolucjonizmu darwinowskiego”, przeł. Dariusz Sagan, Filozoficzne Aspekty Genezy 2005/2006, t. 2/3, s. 68-69 [115-139], https://tiny.pl/gt9nw (19.10.2018). Por. też Michael J. BeHE, Czarna skrzynka Darwina. Biochemiczne wyzwanie dla ewolucjonizmu, przeł. Dariusz Sagan, Biblioteka Filozoficznych Aspektów Genezy, t. 4, Wydawnictwo MEGAS, Warszawa 2008, s. 43-44. Układ ten, zdaniem Behe'ego, 
podstawie nieredukowalnej złożoności należy zakwestionować wtedy, gdy udałoby się wykazać, że mechanizm darwinowski jest w stanie wytworzyć układ o określonym stopniu złożoności (przykładowo wić bakteryjną, składającą się z około 50 rodzajów białek) — nic nie stoi wtedy na przeszkodzie, by twierdzić, że mechanizm ten może wytworzyć dowolny system o mniejszym, równym lub większym stopniu złożoności. ${ }^{27}$ Natomiast wnioskowanie o inteligentnej przyczynie na podstawie wyspecyfikowanej złożoności należy zakwestionować wtedy, gdy udałoby się wykazać, że procesy naturalne wytwarzają wyspecyfikowaną złożoność. ${ }^{28}$

To, jak w obliczu takich prób wykazania zachowaliby się zwolennicy artyficjalizmu lub nadnaturalizmu, to inny problem, który w tym miejscu nie będzie

nie mógł wyewoluować w gradualistycznym procesie darwinowskim, ponieważ nie mogły istnieć żadne, pełniące taką samą funkcję, układy poprzedzające, z których mógłby się rozwinąć. Najczęściej przytaczane przykłady układów nieredukowalnie złożonych to: wić bakteryjna, rzęska eukariotyczna, kaskada krzepnięcia krwi, transport wewnątrzkomórkowy oraz system immunologiczny (por. Dariusz SAGAN, Metodologiczno-filozoficzne aspekty teorii inteligentnego projektu, $B i$ blioteka Filozoficznych Aspektów Genezy, t. 6, Instytut Filozofii Uniwersytetu Zielonogórskiego, Zielona Góra 2015, s. 45-46, https://tiny.pl/g7m72 [19.10.2018]; Dariusz SAGAN, „Ewaluacja ewolucjonistycznych rozwiązań problemu nieredukowalnej złożoności”, Otwarte Referarium Filozoficzne 2009, t. 2, s. 90-95 [89-116], https://tiny.pl/q3mjg [19.10.2018]).

„Wyspecyfikowana złożoność” to kategoria, którą wprowadził William Dembski. Złożoność ta jest cechą pewnej podklasy zjawisk, które z perspektywy wyjaśnień naturalistycznych mają bardzo małe prawdopodobieństwo. Do wykrycia zjawisk charakteryzujących się taką złożonością używa się tak zwanego „filtra eksplanacyjnego”, intelektualnego narzędzia, za pomocą którego odróżnić można skutki działania przyczyn inteligentnych od skutków działań przyczyn nieinteligentnych. Filtr ten jest użyteczny w sytuacjach, gdy można poddać analizom jedynie zaprojektowany obiekt i nie ma się styczności z procesem projektowania (por. Dariusz SAGAN, „Filtr eksplanacyjny: wykrywanie inteligentnego projektu na gruncie nauk przyrodniczych”, Roczniki Filozoficzne 2009, t. 76, nr 1, s. 158-167 [157-193], https://tiny.pl/q3m15 [19.10.2018]; Piotr ByLICA, „Testowalność teorii inteligentnego projektu”, Filozofia Nauki 2003, r. 9, nr 2(42), s. 43-47 [4149], https://tiny.pl/q3m11 [19.10.2018]).

${ }^{27}$ Por. Michael J. BeHE, „Filozoficzne zarzuty stawiane hipotezie inteligentnego projektu: odpowiedź na krytykę", przeł. Dariusz Sagan, Filozoficzne Aspekty Genezy 2004, t. 1, s. 118-119 [115-139], https://tiny.pl/gt9nw (19.10.2018); SAGAN, Metodologiczno-filozoficzne aspekty..., s. 47, 269-286; Robert T. PENnock, „Bóg w lukach wiedzy: argument z niewiedzy i ograniczenia naturalizmu metodologicznego", przel. Dariusz Sagan, Filozoficzne Aspekty Genezy 2012, t. 9, s. 174 [155-185], https://tiny.pl/xhnvt (19.10.2018).

${ }^{28}$ Por. Sagan, Metodologiczno-filozoficzne aspekty..., s. 54, 233-235, 278-280; PenNock, „Bóg w lukach wiedzy...”, s. 176-177. 
podejmowany - czy ich działania odbiegałyby od standardowych, obronnych zachowań innych uczonych, których teoria znalazła się w tarapatach. ${ }^{29}$

$\left(c_{2}\right)$ Naturalizm postrzegany jest także jako zasadniczy składnik uznanej tradycji (wywodzi się z kilkusetletniej praktyki naukowej) ${ }^{30} \mathrm{i}$ „kamień węgielny współczesnej nauki”, ${ }^{31}$ „stanowi [też] zaakceptowaną definicję nauki”. ${ }^{32}$ Mówi się również, że

ze względu na nasze aprioryczne przywiązanie do przyczyn materialnych musimy stworzyć aparat badawczy i zbiór pojęć, które prowadzą do wyjaśnień materialistycznych. ${ }^{33}$

\section{I dlatego}

${ }^{29}$ Por. np. Thomas S. KuHN, „The Function of Dogma in Scientific Research”, w: Alistair C. Crombie (ed.), Scientific Change: Historical Studies in the Intellectual, Social and Technical Conditions for Scientific Discovery and Technical Invention, from Antiquity to the Present, Symposium on the History of Science, University of Oxford 9-15 July 1961, Heinemann, London 1963, s. 348-349 [347-369]; Dariusz SAGAN, „Spór o możliwość wykrywania projektu w naukach przyrodniczych", Scientia et Fides 2015, vol. 3, nr 1, s. 96 [87-113], https://tiny.pl/gz16f (19.10.2018); Dariusz SAGAN, „Molekularny «zegar Paleya» a darwinowska ewolucja”, Ruch Filozoficzny 2005, t. 67, nr 2, s. 289, 295, 301 [289-304], https://tiny.pl/xh8tk (19.10.2018); Wojciech SADY, „Czego Kazimierz Jodkowski nie dostrzega, jeśli o odkrycia naukowe chodzi?”, w: Bylica, Kilian, Piotrowski i Sagan (red.), Filozofia - nauka - religia..., s. 60 [59-64], https://ti ny.pl/g268h (19.10.2018); wypowiedź Feyerabenda w: Renato ParasCandalo and Vittorio Hösle, „Three Interviews with Paul K. Feyerabend”, Teleos. A Quarterly Journal of Critical Thought 1995 , no. 102 , s. 119 [115-148].

${ }^{30}$ Por. Niall Shanks, God, the Devil, and Darwin: A Critique of Intelligent Design Theory, Oxford University Press, New York 2004, s. 141.

${ }^{31}$ Eugenie C. Sсотт, „Darwin Prosecuted: Review of Johnson's Darwin on Trial”, Creation/ Evolution Journal 1993, vol. 13, no. 2, s. 43 [36-47], https://tiny.pl/g28vq (18.10.2018). Por. też Dariusz SAGAN, „Zarzut nietestowalności teorii inteligentnego projektu”, Studia Philosophica Wratislaviensia 2013, vol. 8, fasc. 3, s. 43 [43-59], https://tiny.pl/q33s3 (19.10.2018).

${ }^{32}$ Leonard BRAND, „Naturalizm i jego rola w nauce”, przeł. Paulina Korzeniewska-Nowakowska, Filozoficzne Aspekty Genezy 2016, t. 13, s. 55 [49-74], https://tiny.p1/g2sg3 (19.10.2018).

${ }^{33}$ Richard Lewontin, ,Billions and Billions of Demons”, New York Review of Books 1997, vol. 44, no. 1, https://tiny.pl/gzlb9 (19.10.2018). Por. też Elliott SoBer, „Teoria inteligentnego projektu a nadnaturalizm - o tezie, że projektantem może być Bóg lub istoty pozaziemskie", przeł. Sławomir Piechaczek, Filozoficzne Aspekty Genezy 2007/2008, t. 6/7, s. 38 [21-39], https:// tiny.pl/xhn85 (19.10.2018); Piotr ByLICA, „Konflikt między teizmem i nauką bazująca na naturalizmie - w ujęciu Phillipa E. Johnsona", Zagadnienia Naukoznawstwa 2003, nr 3-4 (157-158), s. 229 [227-238], https://tiny.pl/xh894 (19.10.2018). 
uprawiając naukę, powinniśmy zachowywać się tak, jak gdyby wyjaśnienia naturalistyczne były prawdziwe. ${ }^{34}$

Przedstawione wyżej stwierdzenia są obosieczną bronią. Gdyby wyjaśnienia nienaturalistyczne dominowały w nauce, to ich zwolennicy, broniący uznanej tradycji, również mogliby wygłaszać podobne deklaracje. Mogliby też oczekiwać, że w konflikcie dwu ujęć wygrają ich aprioryczne przywiązania dlatego, że są znane i uznawane.

Tego typu sytuacja miała już miejsce w dziejach nauki. Zwolennicy ostatecznych wyjaśnień krytykowali Newtona i Galileusza za to, że prowadzili swoje badania $\mathrm{w}$ niezgodzie z zastaną tradycją. Zarzuty te padały ze strony poważnych uczonych: Kartezjusza, Huygensa, Leibniza. Newton nie opierał swoich poglądów na pierwszych zasadach, nie wiedział, dlaczego przyroda tak działa, ale nie uważał, by to dyskwalifikowało wiedzę. Nie starał się też wyjaśnić przyczyn ciężkości. Jednakże od fizyki oczekiwano nie tyle matematycznego opisu, co wyjaśnienia przyczyn. Oparta na matematyce, nowa filozofia przyrody Galileusza i Newtona nie odpowiadała zatem na pytania, które w tamtych czasach uznawano za naukowe. Dla Kartezjusza był to krok wstecz. Ten ostatni w liście do Marina Mersenne'a pisał tak:

Wydaje mi się, iż [Galileusz] [...] jedynie szukał przyczyn poszczególnych skutków bez uprzedniego rozważenia [...] pierwszych przyczyn [...]; a zatem budował bez fundamentów. ${ }^{35}$

Zaś Leibniz w liście do Huygensa zarzucał Newtonowi powrót do jakości ukrytych:

Nie rozumiem, jak [...] [Newton] pojmuje ciężar czy przyciąganie. Zdaje się, że we-

\footnotetext{
${ }^{34}$ Jonathan BARTLETT and Eric Holloway, „Introduction”, w: Jonathan BARTLETT and Eric Holloway (eds.), Naturalism and Its Alternatives in Scientific Methodologies: Proceedings of the 2016 Conference on Alternatives to Methodological Naturalism, Blyth Institute Press, Broken Arrow, Oklahoma 2017, s. 1 [1-9] [wyróżnienia dodane]. Por. też William A. Dembski, „Odmiany naturalizmu. Czy któraś forma naturalizmu jest zgodna z teorią inteligentnego projektu?", przeł. Dariusz Sagan, Na Początku... 2005, nr 1-2, s. 46 [45-54], https://tiny.pl/xhkg8 (19.10. 2018).

${ }^{35}$ Cyt. za: Paul K. Feyerabend, Przeciw metodzie, przeł. Stefan Wiertlewski, Wydawnictwo Siedmioróg, Wrocław 1996, s. 63.
} 
dług niego jest to tylko pewna moc niecielesna i niewytlumaczalna. ${ }^{36}$

Natomiast najwybitniejszy kartezjanista, Huygens, pisał do Leibniza tak:

nie zgadzam się z zasadą, [...] która głosi, że wszystkie małe części, jakie można sobie wyobrazić w dwóch lub większej liczbie ciał, przyciągają się bądź dążą do tego, by się wzajemnie zbliżać. [...] nie jestem też przekonany, co do konieczności wzajemnego przyciągania się całych ciał [...]. [Newtona zasada przyciągania] wydaje mi się absurdalna. ${ }^{37}$

$\left(\mathrm{c}_{3}\right)$ Niektórzy twierdzą też, że nigdy nie można odstąpić od wyjaśnień naturalistycznych: ${ }^{38}$

Uczonym wolno formułować tylko takie idee, które odnoszą się do materialnego wszechświata, a mogą je formułować tylko w taki sposób, który pozwala na ich testowanie za pomocą świadectw empirycznych wykrywalnych dla naszych zmysłów. ${ }^{39}$

Podejście takie zakłada zasadę względnej autonomii faktów, w myśl której istotne dla danej teorii fakty dostępne są bez względu na to, czy dla danego ujęcia teoretycznego istnieją ujęcia alternatywne. ${ }^{40}$ Zwolennikami tej zasady byli

\footnotetext{
${ }^{36}$ Cyt za: Jerzy KIERul, Izaak Newton. Bóg, światlo i świat, Oficyna Wydawnicza Quadrivium, Wrocław 1996, s. 201.

${ }^{37}$ Cyt. za: Kierul, Izaak Newton..., s. 201. Por. też Andrzej K. WróBlewski, „Posłowie”, w: Isaac Newton, Matematyczne zasady filozofii przyrody, przeł. Jarosław Wawrzycki, Copernicus Center Press, Kraków 2011, s. 715-718 [715-722].

${ }^{38}$ Por. Niles Eldredge, The Monkey Business: A Scientist Looks at Creationism, Washington Square Press, New York 1982, s. 88. W sprawie pewnych odstępstw od wyjaśnień naturalistycznych por. Kazimierz JoDKowski, „Kreacjonizm a naturalizm nauk przyrodniczych”, Annales Universitatis Mariae Curie-Skłodowska, Sectio I, Lublin-Polonia 1996/1997, vol. 21-22, s. 20-22 [11-26], https://tiny.pl/gplq8 (19.10.2018). O dopuszczaniu wyjaśnień artyficjalistycznych por. wypowiedzi Jodkowskiego i Gazdy w: Piotr Bylica, Małgorzata Gazda, Kazimierz Jodkowski, Krzysztof J. Kilian i Dariusz SAgan, „Dyskusja nad artykułem Adama Trybusa «Program badawczy SETI a teoria inteligentnego projektu»", Filozoficzne Aspekty Genezy 2016, t. 13, s. 225-227 [211-242], https://tiny.pl/g8nvh (19.10.2018).
}

${ }^{39}$ Niles Eldredge, The Triumph of Evolution and the Failure of Creationism, W.H. Freeman and Company, New York 2001, s. 137.

${ }^{40}$ Por. np. Paul K. Feyerabend, „Problems of Empiricism”, w: Robert G. Colodny (ed.), Beyond the Edge of Certainty: Essays in Contemporary Science and Philosophy, Prentice-Hall, Englewood Cliffs, New Jersey 1965, s. 174-175 [145-260]; Paul K. Feyerabend, Against Method: Outline of an Anarchistic Theory of Knowledge, Verso, London 1975, s. 38, 44-46, 179; Paul 
prominentni uczeni, na przykład Isaac Newton ${ }^{41}$ i Henri Poincaré. ${ }^{42} \mathrm{Z}$ zasadą tą, co nietrudno zauważyć, idzie w parze zakaz pochopnego wymyślania kontrhipotez. Podobne przekonania podzielał Stephen J. Gould, odnosił je tylko do zarzuconych już teorii:

ponowne podjęcie odłożonych na bok tematów powinno być odpowiedzią na pojawienie się świeżych danych, przywracających zarzucone poprzednio poglądy do życia. ${ }^{43}$

Zauważono jednak, że utrzymywanie przekonania, zgodnie z którym nie należy dążyć do zastępowania jednej teorii drugą, o ile ta pierwsza nie jest niezgodna z faktami, bywa szkodliwe. Niektóre istotne fakty mogą być odkryte wyłącznie za pomocą teorii alternatywnej względem teorii obowiązującej, a co za tym idzie fakty takie stają się ,niedostępne, jeśli tylko wykluczy się [...] alternatywne teorie". ${ }^{44}$

$\left(\mathrm{c}_{4}\right)$ Twierdzi się również, że

kompetencje [nauki] ograniczają się [wyłącznie] do opisu wiedzy możliwej do uzyskania drogą obserwacji zmysłowej. ${ }^{45}$

K. Feyerabend, „Linguistic Arguments and Scientific Method”, w: Paul K. Feyerabend, Philosophical Papers. Vol. 1. Realism, Rationalism \& Scientific Method, Cambridge University Press, Cambridge - New York - Portchester - Melbourne - Sydney 1981, s. 157 [146-160]; Grzegorz MALEC, „Naturalizm metodologiczny w sporze ewolucjonizmu z kreacjonizmem w świetle poglądów Paula K. Feyerabenda", Filozoficzne Aspekty Genezy 2012, t. 9, s. 139-145 [131-154], https://tiny.pl/xhzfm (19.10.2018); Dunja ŠEŠELJA, „Scientific Pluralism and Inconsistency Toleration", Humana. Mente Journal of Philosophical Studies 2017, vol. 32, s. 4-5 [1-29], https://tiny.pl/gzjgc (19.10.2018).

${ }^{41}$ Por. Newton, Matematyczne zasady..., s. 538.

${ }^{42}$ Por. Henri Poincaré, Nauka i Hypoteza, przeł. Mieczysław Horwitz, Nakład Jakóba Mortkowicza, Warszawa - Lwów 1908, s. 126.

${ }^{43}$ Stephen J. Gould, „Ewolucja jako fakt i teoria”, w: Stephen J. Gould, Niewczesny pogrzeb Darwina. Wybór esejów, przeł. Nina Kancewicz-Hoffman, Biblioteka Myśli Wspótczesnej, Państwowy Instytut Wydawniczy, Warszawa 1991, s. 129 [129-140].

${ }^{44}$ Paul K. Feyerabend, „Jak być dobrym empirystą? Wezwanie do tolerancji w kwestiach epistemologicznych”, w: Feyerabend, Jak być dobrym empirystą..., s. 41-42 [23-61]. Por. też Paul K. Feyerabend, „Realizm i instrumentalizm. Uwagi o logice potwierdzania przez fakty”, w: FeYERABEND, Jak być dobrym empirystą..., s. 180-181 [152-193].

${ }^{45}$ Harry Lee PoE i Chelsea Rose Мyтүк, „Od metody naukowej do naturalizmu metodologicznego. Ewolucja idei”, przeł. Bartosz Błaszczak, Gerard Dmuch, Ewa Komorowska, Iwona 
A zatem każde stwierdzenie dotyczące istnienia, nieistnienia czy też natury stwórcy lub stwórców nie jest z definicji nauką i nie ma dla niego miejsca w dyskusji naukowej lub salach wykładowych. ${ }^{46}$

Nie istnieje taka definicja nauki, która jest w stanie objąć wszystkie przekształcenia, jakim ulega ta ostatnia. ${ }^{47}$ Ponadto stwierdzenia, takie jak cytowane dwa ostatnie, są ,wyważaniem otwartych drzwi”, ${ }^{48}$ gdyż ani nadnaturaliści, ani artyficjaliści nie postulują badania sfery nadprzyrodzonej. ${ }^{49}$ Artyficjaliści poszukują w świecie śladów aktywności Inteligentnego Projektanta, zaś młodoziemscy kreacjoniści, gdy na przykład chcą uzasadnić tezę o młodym wieku Ziemi, to prowadzą badania nad zmiennym tempem poruszania się ziemskich płyt tektonicznych ${ }^{50}$ lub zastanawiają się, w jakim stopniu wiarygodne są metody datowania radioaktywnego. ${ }^{51}$

Kumiszcze, Izabela Obłaczyńska, Katarzyna Piłka, Radosław Plato, Marika Poprawska, Dariusz Sagan, Karolina Stencel, Katarzyna Szot i Piotr Wróblewski, Filozoficzne Aspekty Genezy 2011, t. 8, s. 139 [137-151], https://tiny.pl/xh8gd (19.10.2018)

${ }^{46}$ Ronald H. PINE, „But Some of Them Are Scientists, Aren’t They?”, Creation/Evolution 1984, no. 14, s. 10 [6-18], https://tiny.p1/g2vxk (19.10.2018).

${ }^{47}$ Por. Paul K. Feyerabend, „Podsumowująca niefilozoficzna leśna przechadzka”, w: Paul K. Feyerabend, Dialogi o wiedzy, przeł. Justyna Nowotniak, Fundacja Aletheia, Warszawa 1999, s. 129 [77-142].

${ }^{48}$ Por. JodKowski, „Rozpoznawanie genezy...”, s. 189.

${ }^{49}$ Por. Jodkowski, „Rozpoznawanie genezy...”, s. 189; Kazimierz JodKowski, „Twarde jądro ewolucjonizmu", Roczniki Filozoficzne 2003, t. 51, z. 3, s. 85 [77-117], https://tiny.pl/q3m5j (19. 10.2018); Kazimierz Jodkowski, „Kłopoty teistycznego ewolucjonizmu”, w: Grzegorz BugaJAK i Jacek ТомсzYк (red.), Kontrowersje wokól początków czlowieka, Księgarnia św. Jacka, Katowice 2007, s. 218 [209-224], https://tiny.pl/xhkgl (19.10.2018); Dariusz SAGAN, „Naturalizm metodologiczny - konieczny warunek naukowości?”, Roczniki Filozoficzne 2013, t. 69, nr 1, s. 75 [73-91], https://tiny.pl/q33sb (19.10.2018); SAGAN, „Naturalizm metodologiczny a zagadnienie...", s. 169.

${ }^{50}$ Przykładem takich badań sa prace kreacjonisty, geofizyka i eksperta w projektowaniu komputerowych modeli konwekcji geofizycznej z Los Alamos National Laboratory, Johna R. Baumgardnera. Utrzymuje on pogląd, że pokrywające ziemię płyty geologiczne mogły się kiedyś poruszać tysiące razy szybciej niż obecnie. Jeśli tak było, to w stosunkowo niewielkim okresie czasu mogły zajść duże zmiany geologiczne, co uzasadniałoby część młodoziemskich poglądów kreacjonistycznych (por. JoDKоwsкi, Metodologiczne aspekty..., s. 242-243).

${ }^{51}$ Por. np. Randy IsAaC, „Assessing the RATE Project”, Perspectives on Science and Christian Faith 2007, vol. 59, no. 2, s. 143-146 [143-146], https://tiny.pl/gzj7g (19.10.2018); Marta Cuberbiller, „O metodach datowania radioaktywnego”, w: Małgorzata Gazda (red.), Idź Pod 
$\left(c_{5}\right)$ Utrzymuje się także, że naturalizm metodologiczny jest jedynym kryterium naukowości:

Jeśli w ogóle istnieje jakiekolwiek kryterium, na mocy którego uznaje się jakąś idę̨ za naukową, to jest nim właśnie nakaz odwoływania się do naturalistycznych wyjaśnień zjawisk, a wyjaśnienia te muszą być testowalne wyłącznie w oparciu o nasze zmysły. ${ }^{52}$

Nie istnieje jednak, co przyznają nawet zwolennicy naturalizmu,

żaden kodeks, który tego wymaga [...], jest to ograniczenie arbitralne, ${ }^{53}$

naukowcy dokonali wyboru, aby nie rozważać przyczyn nadnaturalnych. ${ }^{54}$

Arbitralność nie jest tożsama $\mathrm{z}$ dowolnością. Tej pierwszej bronić można wielorako. Omówione niżej grupy argumentów mogą być uznane jako obrona arbitralnego wyboru naturalizmu metodologicznego. Potraktować je można również jako samodzielne argumenty na rzecz naturalizmu.

(d) Następna grupa argumentów skupia się wokół tezy, zgodnie z którą naturalizm metodologiczny zagwarantować ma środowisku naukowemu największy z możliwych konsensus: stać na straży obiektywizmu i neutralizmu. Neutralizm ten

przypomina naukowcom i teologom o potrzebie obiektywizmu badań. ${ }^{55}$

Obiektywizm badań naukowych rozumiany może być na dwa sposoby: mocniejszy i słabszy. Mocniejsze rozumienie zakłada, że istnieją, niezależnie od poznających podmiotów, określonego rodzaju byty i prawdziwe twierdzenia,

Prąd w sporze ewolucjonizm-kreacjonizm, Wydawnictwo POD PRĄD, Lublin 2017, s. 230-233 [230-233], https://tiny.pl/gzj77 (19.10.2018).

${ }^{52}$ Eldredge, The Monkey Business..., s. 82. Por. też Brand, „Naturalizm i jego rola...”, s. 89.

${ }^{53}$ Raymond E. GrizzLe, „Some Comments on the «Godless» Nature of Darwinian Evolution, And a Plea to the Philosophers Among Us", Perspectives on Science and Christian Faith 1992, vol. 43, s. 175-177 [175-177], https://tiny.pl/gzj7d (19.10.2018).

${ }^{54}$ Por. Arminius Mignea, „Methodological Naturalism and Its Creation Story”, w: BartLetT and Holloway (eds.), Naturalism and Its Alternatives..., s. 130 [129-162].

${ }^{55}$ Por. Poe i Mүтүк, „Od metody...”, s. 142. 
które bada nauka. W myśl rozumienia słabszego obiektywizm naukowy polega na przedstawianiu i ocenianiu wyników badań niezależnie od własnych interesów, zaangażowań czy poglądów na świat:

Obiektywizm naukowy nie jest wyzbyciem się własnych przekonań; winny one być naukowo uzasadnione i krytyczne, to znaczy zaś podatne do rozwoju, jeżeli znajdą się stosowne argumenty. ${ }^{56}$

Skupię się tu na rozumieniu słabszym. Stwierdzenie, że przyjęcie naturalizmu prowadzi do akceptacji obiektywizmu, nie mówi nic więcej niż to, że naturalizm nakazuje naturalizm. Jeśli obiektywizm nakazuje naukowo uzasadniać twierdzenia, to uzasadnienia te muszą mieć charakter naturalistyczny, gdyż, jak utrzymują zwolennicy naturalizmu metodologicznego, podstawą metody naukowej jest „systematyczne odrzucanie” wyjaśnień nienaturalistycznych. ${ }^{57}$

Naturalizm metodologiczny uznawany jest też za próbę

stworzenia neutralnego sposobu myślenia, który rozważania teologiczne releguje poza obręb nauki. ${ }^{58}$

Nauka uprawiana w sposób należyty, o ile ma być wspólna dla nas wszystkich, będzie musiała wystrzegać się każdej zależności od poglądów metafizycznych i religijnych, które utrzymują tylko niektórzy z nas, dlatego powinniśmy przyjąć naturalizm metodologiczny. ${ }^{59}$

${ }^{56}$ Wypowiedź Tadeusza Czeżowskiego w: „Sprawozdanie z dyskusji o nauczaniu etyki w szkołach wyższych", Etyka 1966, nr 1, s. 135 [134-136], https://tiny.pl/gzj71 (19.10.2018).

${ }^{57}$ Por. Jacques Monod, Konieczność i przypadek, przeł. Jędrzej Bukowski, Biblioteka Głosu, Warszawa 1979, s. 16; Andrzej PAszewski, „Co zdeterminowane, a co przypadkowe w systemach biologicznych — gdzie zaczyna się wolność?”, Nauka 2005, nr 1, s. 54 [53-66], https://tiny.pl/gzj 78 (19.10.2018); Robert A. Delfino, „Naturalizm metodologiczny i ewolucja”, przeł. Rafał Lizut, w: Piotr Jaroszyński (red.), Ewolucjonizm czy kreacjonizm, Przyszłość Cywilizacji Zachodu, Fundacja „Lubelska Szkoła Filozofii Chrześcijańskiej”, Lublin 2008, s. 147 [137-156], https://ti ny.pl/gzj7b (19.10.2018).

${ }^{58}$ Por. Poe i Mytyk, „Od metody...”, s. 142. Autorzy nie podpisują się pod tym poglądem. Jego zwolennikiem jest natomiast na przykład George Coyne (por. George V. Coyne SJ, „Przypadek jako metoda Boskiego stwarzania”, przeł. Dariusz Sagan, Filozoficzne Aspekty Genezy 2005/ 2006, t. 2/3, s. 40 [39-44], https://tiny.pl/xhkgd [19.10.2018]).

${ }^{59}$ Alvin Plantinga, „Naturalizm metodologiczny?”, przeł. Radosław Plato, Filozoficzne Aspekty Genezy 2014, t. 11, s. 83 [37-93], https://tiny.pl/xh89b (19.10.2018). Jego zdaniem (s. 83) takie wnioski wypływają z Duhemowskiej koncepcji nauki. 
Gdyby faktycznie naturalizm metodologiczny był takim neutralnym podejściem, to pojawia się pytanie, dlaczego osiągnięcia nauki wymuszają na niektórych teologiach korygowanie treści doktryny o Boskim stworzeniu. Przykładowo doktrynę o stworzeniu świata przez Boga i nieustannym nim kierowaniu zastępuje się doktryną o Boskim podtrzymywaniu świata w istnieniu (immanentnej obecności Boga w prawach przyrody). ${ }^{60}$ Odrzuca się też koncepcję powstania człowieka jako specjalnego aktu Boga, ${ }^{61} \mathrm{~W}$ miejsce tego przyjmując, że „Boska kreatywność ujawnia się w procesie ewolucyjnych przemian”. ${ }^{62}$

Zauważono też, że

każda teoria usiłująca wyjaśnić, jak powstało życie, będzie niosła filozoficzne i teologiczne skojarzenia. ${ }^{63}$

Przyrodnicy akceptujący naturalizm metodologiczny przyznają wprost, iż

światopogląd, który właściwy jest ludziom pracującym w naukach przyrodniczych, ma charakter materialistyczny. ${ }^{6}$

\footnotetext{
${ }^{60}$ Por. Piotr ByLıcA, „Główne założenia i problemy teizmu naturalistycznego w sprawie relacji sfery nadprzyrodzonej i świata przyrodniczego", w: Wiesław Dyк (red.), Sozologia systemowa. Tom IV. Biosfera. Czlowiek i jego środowisko w aspekcie przyrodniczym, filozoficznym i teologicznym, Wydawnictwo Naukowe Uniwersytetu Szczecińskiego, Szczecin 2012, s. 56 [5595], https://tiny.pl/q3m1d (19.10.2018).

${ }^{61}$ Por. Bylica, „Główne założenia...”, s. 56; Plantinga, „Naturalizm metodologiczny...”, s. 70-74; William A. Dembski, „Śmierć i Upadek: dlaczego teistyczny ewolucjonizm nie łagodzi problemu zła”, przeł. Dariusz Sagan, Filozoficzne Aspekty Genezy 2013, t. 10, s. 162-163 [159176], https://tiny.pl/xh2nj (19.10.2018).

${ }^{62}$ Józef ŻyciŃski, „Ewolucyjna wizja przyrody a XIX-wieczny teizm”, Studia Philosophiae Christianae 1996, t. 32, nr 1, s. 88 [73-98], https://tiny.pl/gzjr1 (19.10.2018). Por. też Jitse M. vaN DER MeER, „Przekonania towarzyszące, ideologia i nauka”, przeł. Dariusz Sagan, Filozoficzne Aspekty Genezy 2016, t. 13, s. 168 [153-194], https://tiny.pl/gzjrs (19.10.2018).

${ }^{63}$ BEHE, „Nieredukowalna złożoność...”, s. 76.

${ }^{64}$ Por. wypowiedź Lukierskiego w: Bartosz Borczyк, Adam Chmielewski, Andrzej ElżanowSki, Kazimierz Jodkowski, Damian LeszczyŃski, Jerzy Lukierski, Łukasz Nysler i Bogusław PawŁowski, „Dyskusja”, w: Damian Leszczyński (red.), Ewolucja. Filozofia. Religia, Lectiones \& Acroases Philosophicae 2010, vol. 3, s. 155 [155-172], https://tiny.pl/xh8gj (20.10.2018). Por. też Kazimierz JobKowski, „Czy teoria inteligentnego projektu posiada konsekwencje, dotyczące istnienia nadnaturalnego projektanta? Polemika z Elliottem Soberem", Filozoficzne Aspekty Genezy 2007/2008, t. 6/7, s. 47 [41-49], https://tiny.pl/qzq85 (20.10.2018); Kazimierz JodKowski, „,Ruch kreacjonistyczny jest elementem pluralizmu naukowego", Przegląd Filozoficzny - Nowa Seria
} 
Metodologii naturalistycznej, co niejednokrotnie podkreślano, uzasadnienia dostarcza naturalizm metafizyczny. ${ }^{65}$ Odrzuca on istnienie jakichkolwiek zdarzeń lub przedmiotów leżących poza przyrodą. W myśl tego podejścia wszystko, co istnieje, wraz ze wszystkimi istotami żyjącymi, rozwinęło się w bezcelowym, niekierowanym procesie materialnym. Dlatego naturalizm metafizyczny „nie różni się w żaden zasadniczy sposób od materializmu". ${ }^{66}$

(e) Kolejna grupa argumentów ogniskuje się wokół tezy, która głosi, że naturalizm metodologiczny ,jest praktycznym podejściem do uprawiania nauki”. ${ }^{67}$

$\left(e_{1}\right)$ Naturalistycznie uprawiana nauka odnosi sukcesy ${ }^{68}$ i wzbogaca naszą wiedzę: ${ }^{69}$

Naturalizm przyjmuje się dlatego, że w historii nauki okazał się niezwykle skuteczny,

2001, R. X, nr 1(37), s. 246 [241-253], https://tiny.pl/gdw95 (20.10.2018); Martin HiLBERT, „Darwinowskie podziały. Papież, kardynał, jezuita i ewoluująca debata nad pochodzeniem”, przeł. Dariusz Sagan, Filozoficzne Aspekty Genezy 2005/2006, t. 2/3, s. 51, 54-56 [45-63], https://tiny.pl/gz j8m (20.10.2018).

${ }^{65}$ Por. np. Kazimierz JoDKowski, „Naturalizm ewolucjonizmu a wiara religijna. Przypadek Darwina", Przeglad Religioznawczy 1999, nr 1(191), s. 17 [17-34], https://tiny.pl/q3m5c (20.10. 2018); Piotr Bylica and Dariusz SAGAN, „God, Design, and Naturalism: Implications of Methodological Naturalism in Science for Science-Religion Relation”, Pensamiento 2008, vol. 64, núm. 242, s. 624 [621-638], https://tiny.pl/g2884 (20.10.2018); Jerry A. CoYNE, „Science, Religion, and Society: The Problem of Evolution in America”, Evolution. International Journal of Organic Evolution 2012, vol. 66, no. 8, s. 2657 [2654-2663], https://tiny.pl/gzj81 (20.10.2018).

${ }^{66}$ Piotr ByLICA, „Spór o naukowość teorii inteligentnego projektu”, w: Kazimierz JoDKowsKI (red.), Teoria inteligentnego projektu - nowe rozumienie naukowości?, Biblioteka Filozoficznych Aspektów Genezy, t. 2, Wydawnictwo MEGAS, Warszawa 2007, s. 62 [51-78], https://tiny. $\mathrm{pl} / \mathrm{qzq} 8 \mathrm{f}(20.10 .2018)$

${ }^{67}$ Por. Brand, „Naturalizm i jego rola...”, s. 54.

${ }^{68}$ Por. Phil Stilwell, „The Status of Methodological Naturalism as Justified by Precedent”, Studies in Liberal Arts and Sciences 2009, no. 41, s. 236 [229-247], https://tiny.pl/gzjsx (20.10. 2018).

${ }^{69}$ Por. Gerald Skoog, Randy Cielen, Linda Jordan, Janis Lariviere, Larry Scharmann, and Eugenie Scotт, „A NSTA (National Science Teachers Association) Position Statement on the Teaching of Evolution", w: Donald Kennedy, Bruce Alberts, Danine Ezell, Tim Goldsmith, Robert Hazen, Norman Lederman, Joseph McInerney, John Moore, Eugenie Scott, Maxine Singer, Mike Smith, Marilyn Suiter, and Rachel Wood (eds.), Teaching About Evolution and the Nature of Science, National Academy Press, Washington, DC. 1999, s. 124 [124-126], https://tiny.pl/gzj6m (20.10.2018). 
a więc ze względów czysto pragmatycznych. ${ }^{70}$

Takie kategorie jak sukces czy wzrost wiedzy nie mają charakteru neutralnego. Zależą w głównej mierze od tradycji, w której się funkcjonuje: ${ }^{71}$

Osiągnięcia nauki z punktu widzenia jednych tradycji wydają się wspaniałe, z punktu widzenia innych — odrażające, warte jedynie ziewnięcia dla innych jeszcze. ${ }^{72}$

Zaś na oceny sukcesu i wzrostu wiedzy wpływają głównie takie czynniki jak: odmienne tradycje uprawiania nauki, kształtujące różne przekonania i uprzedzenia uczonych; przyjmowane metody badawcze i standardy ocen; zależny od przyjętej perspektywy teoretycznej sposób porządkowania faktów; motywy o charakterze estetycznym, metafizycznym, wolicjonalnym, pozwalające uczonemu obstawać przy wybranej - wbrew faktom i dobrze potwierdzonym teoriom — drodze poszukiwań. ${ }^{73}$

To, czy dane wyjaśnienie uznane może być za zadowalające, zależne jest zatem od akceptowanych, ogólnych perspektyw teoretycznych. ${ }^{74}$ Zaś przyjmowane perspektywy często prowadzą do niezgodnych stanowisk w sprawie adekwatności wyjaśnień. ${ }^{75}$

$\left(\mathrm{e}_{2}\right)$ Naturalizm „uważany jest za jedyną metodę, która jest skuteczna”. ${ }^{76}$

\footnotetext{
${ }^{70}$ Michał Heller, „Nie za bardzo inteligentny projekt”, Copernicus Center 24 grudnia 2014, https://tiny.pl/gzj65 (20.10.2018).

${ }^{71}$ Por. Thomas S. Kunn, Struktura rewolucji naukowych, przeł. Helena Ostromęcka i Justyna Nowotniak, Aletheia, Warszawa 2001, s. 94-96.

${ }^{72}$ Feyerabend, Przeciw metodzie..., s. 230.

${ }^{73}$ Por. np. Paul K. Feyerabend, „Wyjaśnianie, redukcja i empiryzm”, w: Feyerabend, Jak być dobrym empirystą..., s. 84-85 [62-151]

${ }^{74}$ Por. np. Kunn, Struktura rewolucji naukowych..., s. 185; Wilfrid Sellars, „Empiricism and the Philosophy of Mind", w: Wilfrid Sellars, Science, Perception and Reality, Ridgeview Publishing Company, Atascadero, California 1991, s. 173 [127-196]; Steve Clarke, „Naturalism, Science and the Supernatural", Sophia. International Journal of Philosophy and Traditions 2009, vol. 48, s. 128 [127-142].

${ }^{75}$ Por. np. Kuнn, Struktura rewolucji naukowych..., s. 258-259.

${ }^{76}$ Brand, „Naturalizm i jego rola...”, s. 55. Por. też Keith B. Miller, „The Misguided Attack on Methodological Naturalism", w: Jill S. Schneiderman and Warren D. Allmon (eds.), For the Rock Record: Geologists on Intelligent Design, University of California Press, Berkeley — Lon-
} 
Rozpowszechnione za sprawą Feyerabenda przekonania, w myśl których: nie istnieje żadna metoda, którą zawsze można owocnie stosować przy uprawianiu nauki; dokładnie każda, nawet najstaranniej obmyślana, logicznie uzasadniona i wsparta materiałem historycznym, reguła, gdy styka się z rzeczywistością, może pod wpływem rozmaitych okoliczności zostać uchylona - są dość powszechnie i od dawna znane. ${ }^{77} \mathrm{Nie}$ są jednak podzielane przez zbyt wielu filozofów i uczonych. Dominuje, zwłaszcza wśród filozofów i historyków nauki, przekonanie odmienne, zgodnie z którym wyniki, jakie osiągają uczeni, są rezultatem rygorystycznego obstawania przy określonych regułach. ${ }^{78}$

Kontrargumentowano, że tradycyjne, filozoficzne ujęcia zarówno wiedzy naukowej, jak i metody naukowej są błędne, gdyż uczeni nie postępują racjonalnie, w sensie, jaki terminowi temu nadają ci filozofowie nauki, którzy ograniczają racjonalność do jakiegoś wyraźnie wyartykułowanego i ponadhistorycznego zbioru reguł, za którym zawsze należy podążać. ${ }^{79}$ Postępowanie uczonych, ignorujących takie reguły, nie jest ani arbitralne, ani niesystematyczne. Może być za takie uznane jedynie w perspektywie tego typu racjonalistycznych standardów. ${ }^{80}$ Nieobecność wyraźnie wyartykułowanych standardów nie świadczy o tym, że nauka jest irracjonalna. ${ }^{81}$ Kroki uczonych można wytłumaczyć racjonalnie, czyli powiedzieć, dlaczego uczeni postąpili tak, a nie inaczej. ${ }^{82}$ Spora-

don 2009, s. 117 [117-140].

${ }^{77}$ Por. np. Fryderyk Nietzsche, Jutrzenka. Myśli o przesądach moralnych, Wydawnictwo Zielona Sowa, Kraków 2006, s. 207.

${ }^{78}$ Por. np. wypowiedź Feyerabenda w: Parascandalo and Hösle, „Three Interviews...”, s. 117-119; Stephan Fuchs and Joseph H. Spear, „The Social Conditions of Cumulation”, The American Sociologist 1999, vol. 30, no. 2, s. 24 [1-40].

${ }^{79}$ Por. Paul K. Feyerabend, „Preface to the Second Edition”, w: Paul K. Feyerabend, Farewell to Reason, Verso, New York 1996, s. v [v-viii]; wypowiedź Feyerabenda w: Joachim Jung, „Paul K. Feyerabend: Last Interview”, w: John Preston, Gonzalo MunÉvar, and David Lamb (eds.), The Worst Enemy of Science?: Essays in Memory of Paul Feyerabend, Oxford University Press, New York, Oxford 2000, s. 162 [159-168]; Thomas S. Kunn, „Odpowiedź moim krytykom", w: Thomas S. KuHn, Droga po Strukturze. Eseje filozoficzne z lat 1970-1993 i wywiadrzeka $z$ autorem slynnej „Struktury rewolucji naukowych”, wyd. James Conant i John Haugeland, przeł. Stefan Amsterdamski, Wydawnictwo Sic!, Warszawa 2003, s. 149 [117-162].

\footnotetext{
${ }^{80}$ Por. Feyerabend, „Podsumowująca niefilozoficzna...”, s. 106.

${ }^{81}$ Por. KuHN, Struktura rewolucji naukowych..., s. 78-79.

${ }^{82}$ Por. Kunn, „Odpowiedź moim krytykom...”, s. 147; Thomas S. KuHN, „Postscriptum
} 
dycznie kroki te układają się jednak w jakiś nadrzędny, zgodny z uniwersalnymi zasadami schemat. Przypadki potwierdzające występowanie takich schematów trudno uznać za bardziej wyróżnione od tych przypadków, które pozostają z tymi schematami w niezgodzie. ${ }^{83}$

Pogląd, zgodnie z którym rezultaty, jakie osiągają uczeni, są efektem rygorystycznego trzymania się określonych reguł, był podważany nie tylko na płaszczyźnie anarchistycznej. Wykazywano, że metodologiczne deklaracje uczonych niewiele mają wspólnego $\mathrm{z}$ ich rzeczywistą, codzienną praktyką badawczą. Jednym z bardziej wyrazistych przykładów są Newtonowskie wyjaśnienia, na czym polega właściwy sposób postępowania $w$ nauce, $i$ ich ocena przez następne pokolenia uczonych:

nie chciałbym wymyślać hipotez. Cokolwiek bowiem, co nie jest wydedukowane ze zjawisk, musi być nazwane hipotezą, a z drugiej strony — nie ma miejsca na hipotezy w filozofii eksperymentalnej czy to metafizyczne, czy to fizyczne, oparte czy to na własnościach ukrytych, czy to na mechanice. W filozofii eksperymentalnej twierdzenia dedukowane są ze zjawisk i uogólniane metodą indukcji. Nieprzenikliwość, poruszalność, impet ciał oraz prawa ruchu i grawitacji opierają się na tej metodzie. ${ }^{84}$

Stanowisko takie zapisało się w dziejach pod nazwą ,klasycznego empiryzmu". ${ }^{85} \mathrm{O}$ jego powodzeniu świadczy fakt, że The Royal Society uznało je za swoją oficjalną filozofię. ${ }^{86}$ Wsparcia tej metodologii dostarczyły sukcesy, jakimi cieszyła się mechanika Newtona na przestrzeni dwóch następnych stuleci po opublikowaniu Principiów. Później zauważono, że cechą charakterystyczną klasycznego empiryzmu jest swoista schizofrenia. Polega ona na wyraźnym rozdźwięku między wyznawaną filozofią, na gruncie której propaguje się radykalny

(1969)", w: KuHN, Struktura rewolucji naukowych..., s. 342 [301-360].

${ }^{83}$ Por. Paul K. Feyerabend, Zabijanie czasu, przeł. Tomasz Bieroń, Wydawnictwo Znak, Kraków 1996, s. 94-96.

${ }^{84}$ Newton, Matematyczne zasady..., s. 694.

${ }^{85}$ Por. np. Feyerabend, „Problems of Empiricism...”, s. 154; Alan E. Musgrave, „Wpływ Einsteina na filozofię", przeł. Kazimierz Jodkowski, w: Kazimierz JodKowski (red.), Na czym polega racjonalność nauki?, Realizm. Racjonalność. Relatywizm, t. 7, Wydawnictwo UMCS, Lublin 1991, s. 83 [79-105].

${ }^{86}$ Por. Musgrave, „Wpływ Einsteina...”, s. 83; Feyerabend, „Problems of Empiricism...”, s. 156,219 przyp. 4 . 
empiryzm (na przykład unikanie spekulacji i preferowanie obserwacji i eksperymentowania), a sposobem rozwijania teorii fizycznych — tu robi się coś zupełnie innego (na przykład wykracza się poza dziedzinę obserwacji, wprowadza spekulatywne hipotezy). Dysonans między filozoficznymi założeniami a autentyczną praktyka badawczą maskowany był zarówno przez sposób przedstawiania wyników badań ${ }^{87}$ (teorie są niczym innym niż autentycznymi raportami z faktów), ${ }^{88}$ jak i przez propagowanie poglądu, zgodnie z którym po początkowej rewolucji, jaka nastąiła w renesansie, wzrost wiedzy naukowej ma charakter kumulatywny. ${ }^{89}$ Dysonans, o którym tu mowa, trafnie oddaje następujące stwierdzenie:

Jeśli chcecie wydobyć coś od fizyków teoretycznych na temat metod, jakich używają, zachęcam was do stosowania się ściśle do jednej zasady: nie słuchajcie ich słów, ale zwróćcie baczną uwagę na ich czyny. ${ }^{90}$

$\left(\mathrm{e}_{3}\right)$ „Nauka wielokrotnie dowodziła, że metodologiczny naturalizm może zmniejszać obszary niewiedzy, znajdując coraz bardziej wyczerpujące odpowiedzi na zagadki, które kiedyś wydawały się nie do rozwiązania". ${ }^{91}$

Argument ten jest jak najbardziej trafny. Ma jednak istotne ograniczenia. Jego zasadność opiera się na dwóch przesłankach. Zaledwie jedna z nich została wyraźnie wyartykułowana: tylko metodologiczny naturalizm zmniejsza obszary niewiedzy. ${ }^{92}$ Teza, że naturalistycznie uprawiana nauka odnosi sukcesy, nie budzi wątpliwości. W żaden jednak sposób nie prowadzi ona do tez, zgodnie z któ-

\footnotetext{
${ }^{87}$ Por. KuHn, „The Function of Dogma...”, 350-351.

${ }^{88}$ Por. JodKowsKI, „Nienaukowy fundament...”, s. 64-67

${ }^{89}$ Por. Feyerabend, „Problems of Empiricism...”, s. 154-156; Krzysztof J. Kilian, „O fałszowaniu historii swoich własnych odkryć. Newton i Kant”, w: Joanna Dudek i Stefan KonstańczaK (red.), Homo moralis - homo creativus. Prace dedykowane Profesorom Zdzisławowi Kalicie i Krzysztofowi Kaszyńskiemu, Oficyna Wydawnicza Uniwersytetu Zielonogórskiego, Zielona Góra 2015, s. 91 [87-95].

${ }^{90}$ Albert Einstein, The World As I See It, London 1949, s. 131 (cyt. za: Musgrave, „Wpływ Einsteina...", s. 83).

${ }^{91}$ John RenNIE, „15 odpowiedzi na nonsensowne tezy kreacjonistów”, przeł. Karol Sabath, Świat Nauki 2002, nr 9, s. 72 [66-72], https://tiny.pl/gzpws (20.10.2018). Por. też Coyne, ,Science, Religion...”, s. 2657.

${ }^{92}$ Por. Rennie, „15 odpowiedzi...”, s. 72.
} 
rymi: będzie tak w przyszłości i nienaturalistyczne metodologie są bezużyteczne:

Ostatecznie spór teoretyczny jest niczym bitwa. Jedna strona jest pokonana — jeśli ograniczyć się do broni dostępnej w danym czasie. Ale broń nieustannie się zmienia. [...] Tak więc idea dziś odrzucona może jutro zostać dowiedziona jako słuszna. ${ }^{93}$

Przykładowo ID nie jest jeszcze w pełni wykrystalizowanym paradygmatem, co jest zasadniczym powodem różnych słabości eksplanacyjnych tego podejścia. ${ }^{94} \mathrm{Nie} w$ pełni ukształtowała się $\mathrm{w}$ jego ramach tradycja rozwiązywania łamigłówek. ${ }^{95}$ Wspólnota badaczy, zwolenników tego podejścia, nie jest też nazbyt liczna. To samo powiedzieć można o kreacjonistach. ${ }^{96}$

Ostatnie dwa zdania pozwalają przejść do drugiej przesłanki, kluczowej dla tezy o zmniejszaniu obszarów niewiedzy. Im liczniejsza jest wspólnota badaczy, tym większe są szanse na rozwiązanie rozmaitych, uznawanych za istotne, problemów. To, ile problemów rozwiązuje dane ujęcie i jak dobrze to robi, jest wypadkową nie tylko teoretycznej doskonałości danego ujęcia, ale i liczby osób, które w jego ramach pracują, oraz środków, jakimi dysponują. Należy tu również uwzględnić Kuhnowską tezę o stratach. W myśl tej tezy następstwem międzyparadygmatycznej zmiany reguł gry jest to, że niektóre wcześniejsze osią76].

${ }^{93}$ Paul K. Feyerabend, „Fantazje platońskie”, w: Feyerabend, Dialogi o wiedzy..., s. 48 [5-

${ }^{94}$ Por. wypowiedź Kiliana w: Bylica, Jodkowski, Kilian i SAgan, „Dyskusja nad artykułem Adama Groblera...”, s. 26. Por. też Francis J. Bескwiтн, „How To Be an Anti-Intelligent Design Advocate", University of St Thomas Journal of Law \& Public Policy 2009, vol. 4, no. 1, s. 41 [3565], https://tiny.pl/gzpcg (20.10.2018).

${ }^{95}$ Zwolennicy ID, którzy również na to zwracają uwagę, odwołują się do innego ujęcia rozwoju nauki. Na przykład William Dembski swoje przedsięwzięcie określa jako „,naukowy program badawczy”. Wspomniany autor sformułował szereg zaleceń, jakie spełnić powinien ten program (por. William A. DEMBSKI, „Becoming a Disciplined Science: Prospects, Pitfalls, and Reality Check for ID”, https://tiny.pl/gzpct [20.10.2018]. Por. też William A. Dembski, The Design Revolution: Answering the Toughest Questions about Intelligent Design, InterVarsity Press, Downers Grove 2004, s. 306-307; Dariusz SAGAN, „Problem religijnego charakteru teorii inteligentnego projektu”, Studia Philosophica Wratislaviensia 2011, vol. 6, fasc. 4, s. 61-62 [55-74], https://tiny. pl/q336q [20.10.2018]).

${ }^{96}$ Por. np. JoDkowski, „Metafizyczne opowieści...”, s. 75-77; Kazimierz Jodkowski, „Filozoficzna natura sporu ewolucjonizm-kreacjonizm. Refleksje po lekturze tekstu Phillipa E. Johnsona", Na Poczatku ... 2000, nr 7-8 (131-132), s. 215 [211-217], https://tiny.pl/gzpcc (20.10.2018). 
gnięcia uznawane są za bezwartościowe. Na poziomie wyjaśniania faktów proces rozwoju nauki charakteryzują zarówno straty, jak i zyski. Niektóre fakty, uprzednio uznawane za wiarygodne, są usuwane z obszaru nauki. Obarczane są niezauważalnym poprzednio błędem lub uznawane za nieistotne dla nauki, bądź też stwierdza się, że stany rzeczy, o jakich mówiły te fakty, po prostu nie zachodzą. ${ }^{97}$

$\left(\mathrm{e}_{4}\right)$ Naturalizm metodologiczny jest, podyktowaną względami merytorycznymi, idealizacją polegającą na pomijaniu wyjaśnień nienaturalistycznych. ${ }^{98}$

Zauważono, że mówienie o idealizacji ma sens wtedy, gdy pomija się czynniki drugorzędne, które w znaczący sposób nie wpływają na przedmiot badań. Trudno za drugorzędne uznać wyjaśnienia, które są radykalnie odmienne od naturalizmu i, jako takie, dopuszczają zachodzenie takich stanów rzeczy (na przykład nadprzyrodzonych ingerencji czy inteligentnego zaprojektowania niektórych składników organizmów żywych), jakie wyklucza naturalizm. ${ }^{99}$

(f) Kolejna grupa argumentów skupia się na tezie, zgodnie z którą naturalizm metodologiczny jest formą brzytwy Ockhama — realizuje zasadę ekonomii myślenia.

$\left(\mathrm{f}_{1}\right) \mathrm{W}$ myśl mocniejszego sformułowania owej zasady, ${ }^{100}$ gdy znane jest wyjaśnienie uzyskane za pomocą najprostszych środków, można zrezygnować

\footnotetext{
${ }^{97}$ Por. KuHN, Struktura rewolucji naukowych..., s. 191-192; Kazimierz JoDKоwSKI, Wspólnoty uczonych, paradygmaty i rewolucje naukowe, Realizm. Racjonalność. Relatywizm, t. 22, Wydawnictwo UMCS, Lublin 1990, s. 157 przyp. 60; Kazimierz JoDKowsKI, „Interpretacje Kuhnowskiej tezy o niewspółmierności”, Roczniki Filozoficzne 1984, t. 32, z. 3, s. 175 [173-198], https ://tiny.pl/gzpcj (20.10.2018); Rein Vihalemm, „The Kuhn-Loss Thesis and the Case of Phlogiston Theory", Science Studies 2000, vol. 13, no. 1, s. 71 [68-78].

${ }^{98}$ Por. Adam Grobler, „Słabości eksplanacyjne teorii inteligentnego projektu”, Filozoficzne Aspekty Genezy 2013, t. 10, s. 8 [7-16], https://tiny.pl/xh81s (20.10.2018).

${ }^{99}$ Por. wypowiedź Jodkowskiego w: Bylica, Jodkowski, Kilian i SAgan, „Dyskusja nad artykułem Adama Groblera...”, s. 21. Por. też Piotr ByLıcA, „Nauka światopoglądowo neutralna?”, Fronda 2012, nr 63, s. 78-79 [67-80], https://tiny.pl/gkfxr (20.10.2018); Ernan McMuluin, „Odmiany naturalizmu metodologicznego", przeł. Ewelina Topolska, Filozoficzne Aspekty Genezy 2012, t. 9, s. 116-117 [109-129], https://tiny.pl/xh8pf (20.10.2018); Pennock, „Bóg w lukach wiedzy...”, s. 165-170, 183 .

${ }^{100}$ Por. Joachim Metallmann, Zasada ekonomii myślenia. Jej historia i krytyka, E. Wende i S-ka, Warszawa, L. Anczyc i S-ka, Kraków 1914, s. 117.
} 
z wyjaśnień bardziej skomplikowanych. Odwoływanie się do wyjaśnień nienaturalistycznych jest mnożeniem wyjaśnień ponad potrzebę (,nadnaturalne byty nie są niezbędne do wyjaśnienia wszechświata"), ${ }^{101}$ gdyż odwołanie się do przyczyn naturalnych „wystarczy do wyjaśnienia powstania wszechświata, życia i człowieka". ${ }^{102}$

Nie tylko przeciwnicy naturalizmu z rezerwą podchodzą do przekonania, że takie najprostsze wyjaśnienie jest już znane. ${ }^{103}$ Wątpliwości mają również naturaliści:

Hipoteza Oparina-Haldane'a i eksperyment Millera zapoczątkowały systematyczne badania naukowe, które polegają na proponowaniu spójnych logicznie hipotez i próbie ich eksperymentalnej falsyfikacji. Ten program badawczy zapewne nigdy nie doprowadzi do bezspornego ustalenia, jak rzeczy miały się w rzeczywistości. Ogólnie sformułowana hipoteza, że życie powstało w drodze spontanicznych procesów, w sposób nienaruszający znanych praw fizyki, chemii i biologii, w ogóle nie jest podatna na rygorystyczną falsyfikację; można natomiast testować konkretne hipotezy szczegółowe dotyczące poszczególnych etapów przemian prebiotycznych i na ich podstawie konstruować jeden lub więcej alternatywnych scenariuszy wydarzeń. [...] ostatnie lata przyniosły szereg ważnych wyników. Mimo to zagadka powstania i wczesnego rozwoju życia na Ziemi wciąż jest daleka od pełnego wyjaśnienia, co przyznawali nawet najbardziej zasłużeni w tej dziedzinie uczeni. [...] mimo ogromnego postępu wiedzy szczegółowej, nadal ogólny obraz najbardziej frapującego zjawiska, jakie zna biologia, nie jest ostry ani jasny. ${ }^{104}$

$\left(\mathrm{f}_{2}\right)$ Zgodnie ze sformułowaniem słabszym zasady ekonomii należy wybierać prostsze z możliwych wyjaśnień. Naturalizm metodologiczny jest najbardziej ekonomicznym podejściem ze znanych — ogranicza się do wyjaśnień, które przyjmują minimalną ilość założeń ontologicznych — i, jako taki, prowadzi

\footnotetext{
${ }^{101}$ CoYne, „Science, Religion...”, s. 2657.

${ }^{102}$ BylicA, „Konflikt między teizmem...”, s. 230.

${ }^{103}$ Por. np. Dean H. Kenyon, „Kreacjonistyczne ujęcie pochodzenia życia”, przeł. Kazimierz Jodkowski, w: Jodкоwski, Metodologiczne aspekty..., s. 486-487 [482-495]; Bene, Czarna skrzynka Darwina..., s. 146.

${ }^{104}$ January WeINER, „Hipotezy o powstaniu i wczesnej ewolucji życia. Historia dociekań (od Darwina do Millera)", Kosmos 2009, t. 58, nr 3-4, s. 502-503, 523 [501-528], https://tiny.pl/gzpdr (20.10.2018). Por. też Klaus Dose, „The Origin of Life: More Questions Than Answers”, Interdisciplinary Science Reviews 1988, vol. 13, no. 4, s. 348 [348-356].
} 
do przyjęcia ekonomicznego światopoglądu, który jest atrakcyjny dla ludzi nauki. ${ }^{105}$

Niewątpliwie wybór prostszego, bo zawierającego mniej założeń, wyjaśnienia jest bardziej atrakcyjny, gdyż łatwiej poddać je kontroli niż wyjaśnienie zawierające więcej założeń. Niekiedy jednak warto, przynajmniej tymczasowo, na próbę, zrezygnować z prostszego wyjaśnienia na rzecz wyjaśnienia bardziej złożonego, o ile to drugie stwarza nadzieję na rozwiązanie takich problemów, które w ramach pierwszego nie znajdują zadowalającego rozwiązania. Warto też wtedy skorzystać z zasady stronniczości: ${ }^{106}$ przebadać jeden punkt widzenia z perspektywy innego punktu widzenia. Ma to na celu wykrycie słabych punktów badanego ujęcia. ${ }^{107}$

Zauważono, że bez alternatywnych ujęć nie odkryto by wielu istotnych faktów, podważających dominujący punkt widzenia. ${ }^{108}$ Posłużę się tu przykładem. Za taki istotny fakt uznać należy nieredukowalną złożoność. Powstały wyjaśnienia, takie jak: koopcja, narastająca niezbędność, duplikacja genu, luk rzymski, samoorganizacja, ${ }^{109}$ za pomocą których w naturalistyczny sposób tłumaczone jest to, co zwolennicy ID nazwali nieredukowalną złożonością. Bez względu na

\footnotetext{
${ }^{105}$ Por. Ronald G. LARson, „O argumencie z Boga w lukach wiedzy raz jeszcze”, przeł. Joanna Popek, Filozoficzne Aspekty Genezy 2012, t. 9, s. 200 [199-220], https://tiny.pl/xhzg7 (20.10. 2018); Jerzy LuKIERSKI, „Nauka i religia — czy można pogodzić?”, s. 2 [1-5], https://tiny.pl/gzpd2 (20.10.2018).

${ }^{106}$ Por. Paul K. FeYerabend, „Dialectical Materialism and the Quantum Theory”, Slavic Review 1966, vol. 25, no. 3, s. 415 [414-417]; Krzysztof J. KILIAN, „Feyerabend i Lenin a zasada partyjności”, Sofia. Pismo Filozofów Krajów Stowiańskich 2013, nr 13, s. 148-150 [139-154], https:// tiny.pl/gzpdb (20.10.2018).

${ }^{107}$ Por. Paul K. Feyerabend, „On the Improvement of the Sciences and the Arts and the Possible Identity of the Two", w: Robert S. Cohen and Marx W. WARtofsky (eds.), Proceedings of the Boston Colloquium for the Philosophy of Science, 1964/1966. In Memory of Norwood Russell Hanson, Boston Studies in the Philosophy of Science, vol. 3, D. Reidel Publishing Company, Dordrecht 1967, s. 402-405 [387-415].

${ }^{108}$ Por. Feyerabend, „Realizm i instrumentalizm...”, s. 178-179; Oswaldo Chateaubriand, „Ockham's Razor”, O Que Nos Faz Pensa 1990, no. 3, s. 71-72 przyp. 36 [51-75], https://tiny.pl/ gzpfr (20.10.2018).

${ }^{109}$ Wartość tych wyjaśnień omawia Dariusz SAGAN, „Teoria inteligentnego projektu a naukowa debata nad pochodzeniem", w: Јоркошккі (red.), Teoria inteligentnego projektu..., s. 97-106 [79-122], https://tiny.pl/qzq8f (20.10.2018).
} 
to, kto zwycięży w tej rywalizacji, sukces doprowadzi do wzrostu wiedzy: albo naturaliści uszczegółowią swoje wyjaśnienia i pozbędą się istotnych anomalii, przez co uodpornią swoje teorie na nienaturalistyczne ataki, albo zwyciężą zwolennicy ID, czego efektem będzie nowy paradygmat. Zarówno w jednym, jak i w drugim przypadku sformułowane zostaną nowe hipotezy, które prowadzić będą ku innym hipotezom, co zaowocuje uszczegółowieniem badań:

Intelektualne współzawodnictwo, powstałe dzięki odkryciu projektu, przyczyni się do wnikliwszych analiz w profesjonalnej literaturze naukowej i postawi wymóg, by twierdzenia popierać niezbitymi danymi naukowymi. Teoria ta zapoczątkuje powstanie eksperymentalnych podejść i nowych hipotez, których w innym przypadku w ogóle by nie wypróbowano. ${ }^{110}$

(g) Jeszcze inna grupa argumentów dotyczy tezy, zgodnie z którą dopuszczenie wyjaśnień nienaturalistycznych ma szkodliwe następstwa dla uprawiania nauki.

$\left(\mathrm{g}_{1}\right)$ Nie istnieje żadna wiarygodna alternatywa dla naturalizmu metodologicznego ${ }^{111}$ — każdy inny pogląd ,,ma charakter nienaukowy”. ${ }^{112}$

Wobec braku powszechnie akceptowanego kryterium demarkacji podstawowym warunkiem naukowości (lub wiarygodności) danego poglądu jest to, czy mieści się on w głównym nurcie uprawiania nauki. ${ }^{113}$ Drugim wyznacznikiem wiarygodności przekonań jest ich zgodność z akceptowanymi interpretacjami naturalnymi. ${ }^{114}$ Te ostatnie ,są tak bliskie [...] powszechnym przesądom, że

\footnotetext{
${ }^{110}$ Behe, Czarna skrzynka Darwina..., s. 201.

${ }^{111}$ Por. David M.S. Watson, „Adaptation”, w: Report of British Association for the Advancement of Science: Report of the Ninety-Seventh Meeting (Ninety-Ninth Year. South Africa - 1929 July 22 - August 3), London 1930, s. 88 [88-99], https://tiny.pl/gzpfk (20.10. 2018).

${ }^{112}$ Por. Jerry A. Coyne, Ewolucja jest faktem, przeł. Marcin Ryszkiewicz i Wiesław Studencki, Prószyński i S-ka, Warszawa 2009, s. 168-169.

${ }^{113}$ Por. w tej sprawie wypowiedzi Bylicy, Kiliana i Sagana, w: Bylica, Gazda, Jodkowski, KILIAN i SAGAN, „Dyskusja nad artykułem Adama Trybusa...”, s. 6, 11, 26-27.

${ }^{114}$ Por. Krzysztof J. Kilian, „Wzrost wiedzy a zasada tolerancji”, w: Jakub Michalczenia, Jadwiga Mızı́śska i Katarzyna OssowsKa (red.), Poszukiwania filozoficzne. Tom I: Nauka, Prawda. Panu Profesorowi Józefowi Dębowskiemu w darze, Instytut Filozofii Uniwersytetu WarmińskoMazurskiego w Olsztynie, Olsztyn 2014, s. 157-158 [155-173].
} 
wydają się oczywiste, a ich negacje «absurdalne»". ${ }^{115}$

Istnieje przynajmniej pięć argumentów na rzecz utrzymywania zasady tolerancji, ${ }^{116}$ która przestrzega przed pochopnym porzucaniem niewiarygodnych punktów widzenia. ${ }^{117}$ Po pierwsze, nie istnieją środki, za pomocą których wykazać można, że przekonanie o niewiarygodności jakiegoś punktu widzenia świadczyć może o tym, iż punkt ten nie może zostać rozwinięty tak, aby był w stanie stawić czoło najlepiej uzasadnionej teorii. Po drugie, nie da się z góry orzec, dokąd zaprowadzą przyszłe badania takiego punktu widzenia. Po trzecie, to, że jakiemuś niewiarygodnemu punktowi widzenia dano już szansę, której jego zwolennicy nie wykorzystali, nie świadczy o tym, że nie uda się go w przyszłości zmodyfikować i obronić. Po czwarte, niezgodność z faktami lub z wiedzą zastaną nie są ostatecznymi argumentami świadczącymi przeciwko takiemu punktowi. Po piąte, naukowość jakiegoś punktu widzenia nie jest wyznacznikiem jego doskonałości. Uczonego od szarlatana odróżnia stosunek do przyszłych badań

Interpretacje naturalne to przekonania tak mocno połączone z obserwacjami, że: (a) „nie uważamy [...] ich za odrębne założenia”; zaś (b) „uświadomienie sobie ich istnienia i zawartości treściowej wymaga szczególnego wysiłku" (FeYerabend, Przeciw metodzie..., s. 66, 63). Jeszcze inaczej określając interpretacje naturalne, są to przekonania uwarunkowane wbudowaną w język ontologią, która dopóty nie jest zauważana, dopóki nie próbuje się jej podważać. Presuponowana przez język ontologia pozwala jedynie na formułowanie wypowiedzi o określonych rodzajach przedmiotów. Zilustrować to można następującym przykładem. Stwierdzając: „kamień spada w dół”, terminu ,dół” używa się tak, jakby kierunki góra i dół były absolutne. W język potoczny wbudowane jest więc założenie ontologiczne, zgodnie z którym przestrzeń ma charakter anizotropowy. Izotropowego charakteru przestrzeni nie da się wyrazić w tym języku bez dokonania w nim istotnych przeobrażeń. W sprawie różnic między ontologią wbudowaną w język a nabudowaną na języku por. Kazimierz JodKowski i Krzysztof J. KILIAN, „Feyerabendowskie rozwiązanie problemu psychofizycznego", w: Dүк (red.), Sozologia systemowa. Tom IV..., s. 65-66 [61-76], https://tiny .pl/gqkds (20.10.2018).

${ }^{115}$ FeYerabend, „Jak być dobrym empirystą...”, s. 55.

${ }^{116}$ Przeciwko takiemu odrzucaniu niewiarygodnie czy absurdalnie brzmiących punktów widzenia występował Feyerabend:

nigdy nie wiemy z góry, która teoria będzie płodna, a która wadliwa. [...] Absurdalność ja -

kiegoś punktu widzenia [...] nie może się liczyć jako argument przeciwko niemu.

FEYERABEND, „Realizm i instrumentalizm...”, s. 177. Nie ujął on tego nakazu w oddzielną zasadę.

${ }^{117}$ Por. Kilian, „Proliferacja jako narzędzie...”, s. 194-195; Kilian, „Wzrost wiedzy...”, s. 155 . 
(na przykład chęć przezwyciężania istniejących ograniczeń w miejsce obstawania przy rozwiązaniach niezadowalających, próby wymyślenia testów mogących przekształcić mgliste idee w sprawdzalne tezy), a nie pierwotna treść przyjmowanych przez nich teorii. ${ }^{118}$

$\left(\mathrm{g}_{2}\right)$,W nauce nigdy nie wolno rezygnować z wyjaśnienia jakiegoś «materialnego zjawiska» przy pomocy innego «materialnego zjawiska». Rezygnacja z takiego wyjaśnienia i powołanie się na wyjaśnienie «wychodzące poza świat materialny» byłoby zablokowaniem dalszego postępu, a więc sprzeniewierzeniem się naukowej metodzie". ${ }^{119}$

$\mathrm{Z}$ argumentu tego wynika, że zasadniczym składnikiem metody naukowej jest wyjaśnianie jednego materialnego zjawiska za pomocą innego materialnego zjawiska, czyli przestrzeganie zasady naturalizmu metodologicznego. Mało odkrywczy jest zatem argument, w myśl którego na rzecz tego naturalizmu świadczy ten naturalizm.

$\left(\mathrm{g}_{3}\right)$ Jako regulatywna zasada dla nauki naturalizm metodologiczny

jest regułą zachowania uczciwości nauki, chroniąc ją od przemienienia się w nadnaturalizm czy okultyzm. ${ }^{120}$

Przyjęcie wyjaśnień nienaturalistycznych doprowadza do

uznania porażki rozumu, do stracenia nadziei na zrozumienie, do zadowolenia się niewiedzą. ${ }^{121}$

\footnotetext{
${ }^{118}$ Por. Feyerabend, „Realizm i instrumentalizm...”, s. 177-178; Feyerabend, „Linguistic Arguments...”, s. 157. Por. też Kazimierz JodKowsKi, „Filozofia nauki Paula K. Feyerabenda. Stadium umiarkowane", Studia Filozoficzne 1979, nr 11(168), s. 74 [59-75]; Kazimierz JodKowsKi, „Od krytycznego racjonalizmu do anarchizmu metodologicznego", w: Andrzej L. ZAChariasz (red.), Profile racjonalności, Wydawnictwo UMCS, Lublin 1988, s. 142 [135-158]; Kazimierz JoDKowski, „Nauka w oczach Feyerabenda”, w: JoDKOwSKI (red.), Czy sprzeczność może być racjonalna..., s. 248 [227-270].

${ }^{119}$ Michał Heller, Sens życia i sens Wszechświata. Studia z teologii współczesnej, Biblos, Tarnów 2002, s. 44. Por. też ByLICA, „Nauka światopoglądowo neutralna...”, s. 75.

${ }^{120}$ Por. Dembsкi, „Odmiany naturalizmu...”, s. 46. Por. też Andrzej ZAвоєотnY, „Naturalizm metodologiczny w nauce - dylemat teisty", Filozoficzne Aspekty Genezy 2016, t. 13, s. 36-37 [25-48], https://tiny.pl/gzp1f (20.10.2018).

${ }^{121}$ Douglas J. Futuyma, „Cuda a molekuły”, przeł. Dariusz Sagan, Filozoficzne Aspekty Ge-
} 
Za tym argumentem świadczą racje historyczne, łączące się z krytyką koncepcji Boga-zapchajdziury ( $\mathrm{God}$ of the gaps). Koncepcję tę przypisuje się siedemnasto- i osiemnastowiecznym fizykoteologom, Newtonowi, Boyle'owi ${ }^{122}$ i Hooke'owi. Uczeni ci wskazywali na istnienie pewnych szczególnych aspektów rzeczywistości przyrodniczej, które zadowalająco miały być wyjaśniane przez empirycznie wykrywalne przejawy Boskiego działania w świecie. ${ }^{123}$ Jedna z najbardziej znanych wypowiedzi, która ilustruje to podejście, pochodzi od Newtona:

nie sądzę, by dało się wyjaśnić [ruch planet wokół Słońca] za pomocą samych przyczyn naturalnych; zmuszony jestem przypisać je działaniu i pomysłowości świadomego Czynnika. ${ }^{124}$

Sukcesy w nienterwencjonistycznym wyjaśnianiu zjawisk, które uprzednio nie poddawały się czysto przyrodniczym wyjaśnieniom, doprowadziły do przekonania, w myśl którego

nawet jeśli istnieją luki w obecnej wiedzy naukowej, racjonalnie jest spodziewać się, że i one zostaną wypełnione powszechnie akceptowanymi naturalistycznymi wyjaśnieniami. ${ }^{25}$

nezy 2004, t. 1, s. 68-69 [65-69], https://tiny.pl/xhzmf (21.10.2018). Por. też Tom GiLson, „Naturalizm metodologiczny, teizm metodologiczny i regularyzm”, przeł. Dariusz Sagan, Filozoficzne Aspekty Genezy 2017, t. 14, s. 90 [89-98], https://tiny.pl/gz879 (21.10.2018).

${ }^{122}$ Nie wszyscy interpretują mechanicyzm Boyle'a w ten sposób:

wszechmoc Boga nie jest dla niego „substancją” do „zalepiania dziur w ludzkiej wiedzy”.

Radosław KaziBut, „Potentia absoluta i epistemiczny układ odniesienia Roberta Boyle’a”, Filo-Sofija 2015, vol. 15, nr 30, s. 114 [111-122], https://tiny.pl/gzntk (21.10.2018).

${ }^{123}$ Por. np. Bylica, „Główne założenia...”, s. 81-82; Włodzimierz Skoczny, „Dziedzictwo fizykoteologii we współczesnej myśli chrześcijańskiej”, Zagadnienia Filozoficzne w Nauce 1991, vol. 13, s. 79-85. Tekst elektroniczny ma odrębną numeracje stron: por. s. 3-4 [1-7], https://tiny.pl /gzlm6 (21.10.2018).

${ }^{124}$ Isaac Newton, Four Letters from Sir Isaac Newton to Doctor Bentley Containing Some Arguments in Proof of a Deity, London 1756, List I, s. 3 [1-11], https://tiny.pl/gzlmz (21.10. 2018).

${ }^{125}$ Bylica, „Główne założenia i problemy...”, s. 67; Colin A. Russell, „Views of Nature”, w: Gary B. Ferngren (ed.), History of Science and Religion in the Western Tradition. An Encyclopedia, Garland Publishing, Inc., New York \& London 2000, s. 47 [43-55]. 
Przekonanie to prowadzi do „apriorycznego zaangażowania w naturalizm metodologiczny”, ${ }^{126}$ gdy dodatkowo zakłada się, że ,nie istnieją luki w naturalistycznym opisie zdarzeń zachodzących w sferze empiryczno-przyrodniczej”, ${ }^{127}$ czyli że naturalistyczne wyjaśnienia są wystarczające do adekwatnego opisu świata. Warto w tym miejscu odnotować, że jedyny argument, który bardzo słabo potwierdza to założenie, głosi, iż naturalistycznie uprawiana nauka odnosi sukcesy. Zauważono też, że owo aprioryczne zaangażowanie może mieć negatywne następstwa:

Skąd wiemy, że badania empiryczne świata przyrody mogą odkryć tylko skutki przypadku i konieczności, lecz nie projektu? Skąd wiemy, że ślepe przyczyny naturalne to najlepsze, do czego nauka ma dostęp, badając przyrodę? ${ }^{128}$

Może [...] dojść do osobliwej sytuacji, w której naukowiec będzie wolał ufać spekulacjom pozbawionym należytego poparcia w empirii zamiast odwołać się do Boga czy jakiegoś innego nienaturalistycznego wyjaśnienia. ${ }^{129}$

$\left(\mathrm{g}_{4}\right)$ W myśl słabszej postaci powyższego $\left(\mathrm{g}_{3}\right)$ argumentu:

dowolna nauka może istnieć tylko pod warunkiem przyjęcia założenia, że Bóg nie interweniuje w przebieg zjawisk, i sprawdzenia, jak daleko można się posunąć w ich wyjaśnianiu. ${ }^{130}$

Wykluczenie z naukowego wyjaśniania bezpośrednich Boskich ingerencji umożliwia uprawianie nauki:

Można oczywiście być wierzącym, można wierzyć, że Bóg istnieje. Ale ów Bóg musi mieć pewne ograniczenia i nie może się wtrącać $\mathrm{w}$ procesy przyrodnicze. Jeśli ktoś już chce Bogu przypisać jakąś funkcję, to może nią być akt początkowego stworzenia świata, ewentualnie stworzenia praw - i koniec. W innym wypadku nauka byłaby

\footnotetext{
${ }^{126}$ Steven Lloyd, „«God of the Gaps»: A Valid Objection?”, Origins 2006, vol. 42, s. 9 [710], https://tiny.pl/gzlgr (21.10.2018).

${ }^{127}$ Piotr ByLicA, „Zarys modelu poziomów analizy w badaniach relacji nauki i religii”, Filozoficzne Aspekty Genezy 2012, t. 9, s. 252 [221-253], https://tiny.pl/xhzml (21.10.2018).

${ }^{128}$ Dembski, „Odmiany naturalizmu...”, s. 48.

${ }^{129}$ SAGAN, „Naturalizm metodologiczny a zagadnienie...”, s. 172.

${ }^{130}$ Steven Weinberg, Sen o teorii ostatecznej, przeł. Piotr Amsterdamski, Alkazar, Warszawa 1994, s. 312.
} 
niemożliwa. Wyobraźmy sobie, że Bóg od czasu do czasu się wtrąca — tu coś zmieni, tam coś zmieni. Cóż wówczas warta byłaby nauka? Niemożliwe byłoby przewidywanie, a tym samym testowanie. Nauka odrzuca takie rozwiązania. ${ }^{131}$

$\left(\mathrm{g}_{5}\right)$,Jeśli nauka włączy to, co nadnaturalne, do swojej domeny wyjaśnień, to wszystko ujdzie [anything goes]". ${ }^{132}$

Feyerabendowską ,zasadę” można interpretować na wiele sposobów, co jest efektem przede wszystkim tego, że amerykański filozof nie wyrażał się w tej kwestii jasno. Jednym z możliwych, choć niezgodnych z intencjami Feyerabenda, jest nadawanie owej „zasadzie” wykładni nihilistycznej. ${ }^{133}$ Zgodnie z tą ostatnią:

jedyną regułą jest [...] [to], że nie istnieją żadne reguły, ${ }^{134}$

a zatem

wszystko jest dozwolone. ${ }^{135}$

Zaś końcowym tego rezultatem jest to, że

wszystkie reguły metodologiczne są bezużyteczne. ${ }^{136}$

\footnotetext{
${ }^{131}$ Wypowiedź Jodkowskiego, streszczającego pogląd Darwina i dzisiejszych naturalistów metodologicznych w: Borczyк, ChMielewski, Elżanowski, Jodkowski, Leszczyński, Lukierski, NysLER i PawŁowski, „Dyskusja...”, s. 157-158; Grzegorz BugaJak, „Naturalizm nauki a działanie Boga w świecie”, w: Janusz Mączka i Piotr UrbańcZYk (red.), Teologia nauki, Copernicus Center Press, Kraków 2015, s. 153 [145-172].

${ }^{132}$ Massimo Pigliucci, Denying Evolution: Creationism, Scientism and the Nature of Science, Sinauer Associates, Sunderland, Massachusetts 2002, s. 66 (cyt. za: Dariusz SAGAN, „Spór o użyteczność teorii inteligentnego projektu dla nauki”, Kultura i Edukacja 2013, nr 3(96), s. 32 [28-49], https://tiny.pl/xhhg3 [21.10.2018]).

${ }^{133}$ Por. Kilian, Poglądy filozoficzne..., s. 153-163.

${ }^{134}$ Jean Curthoys and Wal Suchting, „Feyerabend's Discourse Against Method: A Marxist Critique", Inquiry 1977, vol. 20, no. 2-3, s. 251 [243-397].

${ }^{135}$ Gunnar Andersson, Criticism and the History of Science: Kuhn's, Lakatos's, and Feyerabend's Criticism of Critical Rationalism, E.J. Brill, Leiden — New York — Köln 1994, s. 5.

${ }^{136}$ Denise Russell, „Anything Goes”, Social Studies of Science 1983, vol. 13, no. 3, s. 447 [437-464].
} 
Sformułowano również antynihilistyczną wykładnię Feyerabendowskiej „zasady”:

Próbuj wszystkiego, patrz, czy może się przydać. ${ }^{137}$

Zgodnie z nią nie jest tak, że nie istnieją żadne reguły adekwatnie opisujące praktykę naukową:

Propaguję pogląd, że wszystkie reguły mają swoje granice, lecz nie wyprowadzam stąd wniosku, że powinniśmy żyć bez reguł. [...] Wręcz przeciwnie, chcę powiększać nasz zasób reguł — im więcej ich mamy, tym lepiej. ${ }^{138}$

Wykładnia ta nie pozostaje zatem w niezgodzie z twierdzeniem, że w określonej sytuacji jakaś metoda będzie lepsza od innej. Podważa się tu jedynie sensowność wszelkich prób przekształcania reguł przyjmowanych doraźnie dla rozwiązywania konkretnych problemów w powszechnie obowiązujące, ponadhistoryczne reguły. ${ }^{139}$

Przywoływany argument $\mathrm{w}$ świetle antynihilistycznej wykładni i jednego z Feyerabendowskich uzupełnień:

anything goes znaczy zatem jedynie tyle, co „nie ograniczaj swojej wyobraźni”, ponieważ nawet bardzo niedorzeczna idea prowadzić może do godnych zaufania wyników", ${ }^{140}$

nabiera innego sensu, zachęcając również i do badania alternatywnych punktów widzenia.

\footnotetext{
${ }^{137}$ Marx W. Wartofsky, „How to Be a Good Realist”, w: Gonzalo MunÉvar (ed.), Beyond Reason: Essays on the Philosophy of Paul K. Feyerabend, Boston Studies in the Philosophy of Science, vol. 132, Kluwer Academic Publishers, Dordrecht - Boston — London 1991, s. 28 [2540].

${ }^{138}$ Paul K. Feyerabend, „«Racjonalność» badania”, przeł. Zdzisław Kowalski, w: JodKowsKi (red.), Czy sprzeczność może być racjonalna..., s. 278 [271-289].

${ }^{139}$ Por. Kazimierz Jodkowski, „«Wszystko ujdzie». Anarchizm epistemologiczny Paula K. Feyerabenda", Akcent 1982, nr 2(8), s. 129-131 [127-134].

${ }^{140}$ Paul K. Feyerabend, The Tyranny of Science, Polity Press, Cambridge UK - Malden USA 2012, s. 130-131.
} 
$\left(\mathrm{g}_{6}\right)$ Wyjaśnienia nienaturalistyczne to „ostatniego sortu” „wyjaśnienia dla dotkniętych intelektualnym ubóstwem", przyjmowane pochopnie wtedy, gdy wyjaśnienia naturalistyczne zawodzą. A co gorsza, gdy raz dopuści się wyjaśnienia nienaturalistyczne, można tak postępować w nieskończoność. ${ }^{141}$

Argument ten ma wybitnie propagandowy charakter. Nie chodzi tu wyłącznie o użyte w nim słownictwo. Owszem, można permanentnie odwoływać się do łatwiejszych wyjaśnień wtedy, gdy zawodzą trudniejsze. Zauważono jednak, że de facto tak się nie postępuje. Poparto to również przekonującym przykładem wykraczającym poza kontrowersję naturalizm-nienaturalizm. W mechanice kwantowej mówi się o procesach indeterministycznych. Przykładowo rozpad atomów pierwiastków promieniotwórczych podlega jedynie prawidłowościom statystycznym. Można tylko przewidzieć prawdopodobieństwo tego, że dany atom takiego pierwiastka rozpadnie się $\mathrm{w}$ określonym czasie. Jeśli raz $\mathrm{w}$ nauce dopuszczono wyjaśnienia indeterministyczne, to nie ma żadnego powodu, by nie stosować takich wyjaśnień dla każdego problemu, który, w danej chwili, wymyka się wyjaśnieniom deterministycznym. ${ }^{142}$

Jest [zatem] możliwe, aby o każdym zdarzeniu, które zajdzie, uczeni mówili, że jest efektem procesów indeterministycznych. ${ }^{143}$

Tak się jednak nie dzieje. Nie jest tak, że naukowcy powołują się na wyjaśnienie indeterministyczne, gdyż jest ono najprostsze i nie wymaga wysiłku. Przemawiają za nim pewne przesłanki, ale nie byłoby czymś właściwym z perspektywy nauki, gdyby naukowcy korzystali z tego wyjaśnienia nawet wtedy, gdy takich przesłanek brak. ${ }^{144}$

Podsumowując tę część rozważań, zauważyć należy, że mimo iż naturalizm metodologiczny uznawany jest za „teorię-matkę wszystkich nauk przyrodniczych" i za paradygmat tego, jak należy uprawiać naukę, ${ }^{145}$ to żaden z omówio-

\footnotetext{
${ }^{141}$ Pennock, Tower of Babel..., s. 294, 292.

${ }^{142}$ Por. SAGAN, „Spór o użyteczność...”, s. 37.

${ }^{143}$ Bradley Monton, Seeking God in Science: An Atheist Defends Intelligent Design, Broadview Press Inc., Toronto 2009, s. 63.

${ }^{144}$ SAGAN, ,Spór o użyteczność...”, s. 37.

${ }^{145}$ Por. Kazimierz JodKowski, ,Spisek Darwina”, w: LeszczyŃski (red.), Ewolucja. Filozofia. Religia..., s. 276 [265-227], https://tiny.pl/q3m53 (21.10.2018); Kazimierz JodKowski, „Darwinowska teoria ewolucji jako teoria filozoficzna", w: Stefan Konstańczak i Tomasz Turowski
} 
nych argumentów na rzecz naturalizmu metodologicznego nie daje podstaw po temu, by decyzja odrzucania wyjaśnień nienaturalistycznych mogła być bezapelacyjnie uznana za kamień węgielny współczesnej nauki. Zapewne właśnie dlatego przyznaje się, że „falsyfikacja paradygmatu naturalistycznego jest możliwa". ${ }^{146} \mathrm{~W}$ następnym paragrafie omówię warunki odstępowania od wyjaśnień naturalistycznych.

\section{Argumenty na rzecz dopuszczania rewizji naturalizmu metodologicznego}

W ramach podejścia dopuszczającego rewizję naturalizmu pojawiają się dwie grupy argumentów. Jedna z nich (a) nie podaje konkretnych warunków odstąpienia od wyjaśnień naturalistycznych. Druga (b) warunki takie formułuje.

W ramach grupy pierwszej mówi się w sposób bardzo ogólny, że naturalizm metodologiczny jest założeniem roboczym, z którego należy zrezygnować, gdy zacznie ono zawodzić. ${ }^{147}$

$\left(a_{1}\right)$ Ograniczenie nauki do sfery naturalnej powinno być przeprowadzone prowizorycznie i opierać się na wcześniejszych niepowodzeniach wyjaśnień nadnaturalistycznych i sukcesach wyjaśnień naturalistycznych. ${ }^{148}$

Zatem, gdy sytuacja ulegnie zmianie i wyjaśnienia nadnaturalistyczne zaczną odnosić sukcesy, a naturalistyczne - porażki, dopuścić należy te pierwsze. Jednakże sukces jest kategorią, która nie ma charakteru neutralnego. Przykładowo jeden ze zwolenników wyjaśnień naturalistycznych stwierdził, iż

ostatnie lata przyniosły szereg ważnych wyników [...] [świadczących o tym], że życie

(red.), Filozofia jako mądrość bycia, Oficyna Wydawnicza Uniwersytetu Zielonogórskiego, Zielona Góra 2009, s. 22 [17-23], https://tiny.pl/q3m56 (21.10.2018).

${ }^{146}$ Massimo Pigliucci, Tales of the Rational: Skeptical Essays About Nature and Science, Freethought Press, Atlanta, Georgia 2000, s. 21. Por. też Delfino, „Naturalizm metodologiczny...", s. 154.

${ }^{147}$ Por. SAGAN, „Naturalizm metodologiczny a zagadnienie...”, s. 77.

${ }^{148}$ Por. Erkki V.R. KoJonen, „Methodological Naturalism and the Truth Seeking Objection”, International Journal for Philosophy of Religion 2016, vol. 79, no. 3, s. 3 [1-26], https://tiny.p1/gk fxk (21.10.2018). 
powstało w drodze spontanicznych procesów. ${ }^{149}$

Zaś jeden z przeciwników dominacji takich wyjaśnień doszedł do wniosku, iż błędnie się

sądzi, że symulacyjne eksperymenty Millera i inne podobne typy eksperymentów stanowią mocne empiryczne poparcie dla naturalistycznego pochodzenia życia. ${ }^{150}$

Przy takich ocenach należy również uwzględnić, charakteryzowaną w poprzednim paragrafie, tezę o stratach.

Nie da się również wyznaczyć limitu czasowego tolerowania niepowodzeń jakiegoś sposobu wyjaśniania. Nie istnieją środki, za pomocą których z góry można orzec, że krytykowany punkt widzenia nie może zostać rozwinięty tak, aby był w stanie stawić czoło największym trudnościom. ${ }^{151}$

$\left(\mathrm{a}_{2}\right) \mathrm{Z}$ naturalizmu należy zrezygnować wtedy, gdy znane jest wyjaśnienie bardziej przekonujące ${ }^{152}$ lub wtedy, gdy istnieje po temu dobry naukowy powód: ${ }^{153}$

nie wolno się odwoływać do przyczyn nadnaturalnych — przynajmniej dopóty, dopóki procesy naturalne zadowalająco wyjaśniają zjawiska przyrodnicze. ${ }^{15}$

To, co zostało powiedziane przy okazji krytyki poprzedniego argumentu, odnosi się również i do tego argumentu. Ponadto uznanie czegoś za dobry na-

\footnotetext{
${ }^{149}$ Weiner, „Hipotezy o powstaniu...”, s. 502.

${ }^{150}$ KenYon, „Kreacjonistyczne ujęcie...”, s. 486.

${ }^{151}$ Por. np. Feyerabend, „Ku pocieszeniu...”, s. 207-208.

${ }^{152}$ Por. Loren Petrich, „Artefakty zwierzęce i pozaziemskie — inteligentnie zaprojektowane?", przeł. Dariusz Sagan, Filozoficzne Aspekty Genezy 2009/2010, t. 6/7, s. 152-153 [139153], https://tiny.pl/xh8hp (21.10.2018). Przywoływany autor nie formułuje explicite warunków oceny konkurujących hipotez.

${ }^{153}$ Por. Thomas Woodward, „Istota sporu darwinizmu z teorią inteligentnego projektu: przyrodnicza symfonia makroewolucji”, przeł. Dariusz Sagan, Filozoficzne Aspekty Genezy 2007/ 2008, t. 6/7, s. 15 [7-20], https://tiny.pl/xhnkv (21.10.2018).

${ }^{154}$ Antoni Hoffman, „Wstęp”, w: Richard Dawkins, Ślepy zegarmistrz, czyli jak ewolucja dowodzi, że świat nie zostal zaplanowany, przeł. Antoni Hoffman, Biblioteka Myśli Współczesnej, Państwowy Instytut Wydawniczy, Warszawa 1994, s. 9 [5-10].
} 
ukowy powód lub za wyjaśnienie bardziej przekonujące uzależnione jest od uprzednio zaakceptowanej definicji naukowości, która, co widoczne było w poprzednim paragrafie, bazuje na naturalistycznym rozumieniu nauki. ${ }^{155}$

Powyższe kontrargumenty uzupełnić warto o jeszcze jedną tezę. Zgodnie $\mathrm{z}$ nią

z tego, że teraz jakichś zjawisk przyrodniczych nie wyjaśnia się zadowalająco przez odwołanie się do procesów naturalnych, nie wynika, że w przyszłości to nie nastąpi. ${ }^{156}$

Skupię się obecnie na tej grupie argumentów, która podaje konkretne warunki odstąpienia od wyjaśnień naturalistycznych.

$\left(b_{1}\right)$ Pierwszy argument $\mathrm{z}$ tej grupy odwołuje się do określonego rodzaju danych empirycznych:

W myśl tego, co nazwaliśmy tymczasowym lub pragmatycznym naturalizmem metodologicznym, naturalizm metodologiczny jest tymczasowym i empirycznie uzasadnionym zobowiązaniem do akceptacji naturalistycznych przyczyn i wyjaśnień, które w zasadzie jest odwoływalne przez nadzwyczajne [przytłaczające i niewątpliwe] świadectwa empiryczne. ${ }^{157}$

Same w sobie świadectwa empiryczne nie są ani przytłaczające, ani niewątpliwe, gdyż tylko od uprzednio przyjętej teorii zależy to, czy świadectwa takie uznane zostaną za istotne. ${ }^{158}$ Zaś nadzwyczajne świadectwa, o ile termin ten rozumiany będzie po Kuhnowsku, ${ }^{159}$ to nic innego niż anomalie. Te ostatnie,

\footnotetext{
${ }^{155}$ Por. w tej sprawie komentarz Nagela (NAGEL, „Public Education...”, s. 201-202) do procesu Kitzmiller et al. v. Dover Area School District et al.

${ }^{156}$ JodKowsKi, Metodologiczne aspekty..., s. 313.

${ }^{157}$ Maarten Boudry, Stefaan Blancke, and Johan Braeckman, „How Not to Attack Intelligent Design Creationism: Philosophical Misconceptions About Methodological Naturalism”, Foundations of Science 2010, vol. 15, no. 3, s. 227-244. Tekst elektroniczny ma odrębną numerację stron, s. 4. Fragment w nawiasie kwadratowym pochodzi ze s. 17 [1-21], https://tiny.pl/gzl4j (21.10. 2018).

${ }^{158}$ Por. Kuhn, Struktura rewolucji naukowych..., s. 55-64; Feyerabend, „Realizm i instrumentalizm...”, s. 175-177; Kazimierz JoDKowski, „W poszukiwaniu twardego jądra ewolucjonizmu”, Filozofia Nauki 2001, nr 2(34), s. 14 [7-18], https://tiny.pl/xh81h (21.10.2018).

${ }^{159}$ Boudry, Blancke i Braeckman użyli tu nazwy extraordinary empirical evidence.
} 
wzięte w izolacji, nie podważają przyjętej perspektywy badawczej. (Dawno temu zauważono, że „nie istnieje teoria, która zgadza się ze wszystkimi obserwacjami”. ${ }^{160}$ ) Dopiero wtedy,

gdy grupa specjalistów nie potrafi już unikać anomalii burzących obowiązującą tradycję praktyki naukowej, rozpoczynają się nadzwyczajne badania, w wyniku których zostaje w końcu wypracowany nowy zespół założeń, dostarczający podstawy nowej praktyki badawczej. ${ }^{161}$

$\left(\mathrm{b}_{2}\right)$ Drugi argument $\mathrm{z}$ tej grupy opiera się na metodologicznej decyzji rozszerzenia zakresu terminów „nauka” i ,wiedza”. Ten pierwszy rozumiany jest w sposób klasyczny:

termin „nauka” wywodzi się z łacińskiego słowa scientia, które miało kiedyś szerszy zakres niż dzisiaj. Odnosiło się ono do wszystkich form wiedzy znanych w tamtych czasach i uważanych za prawowitą wiedzę, a tym samym obejmowało także dziedziny, takie jak metafizyka i teologia. Odrzucenie tego szerszego znaczenia może, w konsekwencji, sugerować, że takim dziedzinom odmawia się poznawczej zasadności. ${ }^{162}$

Podobnie sprawy mają się z terminem drugim:

Istnienie Boga jest czymś, o czym osoby wierzące wiedzą, w najpełniejszym sensie czasownika „wiedzieć”. Zależność od Stwórcy jest częścią istoty każdej stworzonej rzeczy: gdyby więc ktoś chciał określić istotę jakiegoś rodzaju naturalnego, pomijając tę zależność, to taka definicja byłaby z konieczności niekompletna. ${ }^{163}$

Sam argument wygląda tak:

jeśli naturalizm metodologiczny nie jest sprzężony z jakąs formą scjentyzmu (w szczególności z przekonaniem, że wszystkie teologicznie motywowane teorie są irracjonalne), to wierność naturalizmowi metodologicznemu [...] nie stanowi podstawy do bez-

${ }^{160}$ Phillip G. Frank, „The Variety of Reasons for the Acceptance of Scientific Theories”, w: Phillip G. Frank, The Validation of Scientific Theories, The Beacon Press, Boston 1956, s. 3 [328] (cyt. za: Artur KoTERSKI, Weryfikacjonistyczne kryteria demarkacji w filozofii nauki Kola Wiedeńskiego, Centrum Nauki Języka Angielskiego Metodą Allana, Akces, Spółka z o.o., Poznań 2002, s. 175).

${ }^{161}$ KuHN, Struktura rewolucji naukowych..., s. 27.

${ }^{162}$ McMullin, „Odmiany naturalizmu...”, s. 123.

${ }^{163}$ McMuluin, „Odmiany naturalizmu...”, s. 123 przyp. 18. 
zasadnego eliminowania wyjaśnień przyrodniczych, których jedyna motywacja znajduje ugruntowanie w jakiejś konkretnej interpretacji Pisma Świętego. ${ }^{164}$

Podejście takie sprowadza się do akceptacji zasady inkluzji. Zgodnie z nią wyjaśnienia dotyczące bezpośredniego działania boskiego sprawcy mogą być składnikiem nauk przyrodniczych. ${ }^{165}$ Jednak naturalizm metodologiczny bazuje na zasadzie ekskluzji, ${ }^{166}$ która zakazuje przyjmowania tego typu wyjaśnień (,wymaga, aby w wyjaśnieniach naukowych stosować jedynie materialne przyczyny" ${ }^{167}$ ).

W omawianym przypadku akceptacja zasady inkluzji prowadzi do konieczności przeprowadzenia dwóch dystynkcji i - co za tym idzie - akceptacji dwóch decyzji metodologicznych. Po pierwsze, odróżnić należy tak zwany „mocny naturalizm metodologiczny” (w myśl którego ,jedynym prawowitym źródłem wiedzy o świecie przyrody są nauki przyrodnicze" ${ }^{168}$ ) od tak zwanego „umiarkowanego naturalizmu metodologicznego". Zgodnie z tym ostatnim, z jednej strony odróżnia się wiedzę o przyrodzie uzyskaną na gruncie nauk przyrodniczych od wiedzy uwierzytelnionej w inny sposób (na przykład teologicznie). $Z$ drugiej zaś strony ten drugi rodzaj wiedzy uznawany jest za składnik wyjaśniania naukowego. ${ }^{169}$

Po drugie, odróżnić należy naukę teistyczną (,my, chrześcijanie, musimy prowadzić rozważania z perspektywy chrześcijańskiej, potrzebujemy teistycznej nauki”, ${ }^{170}$ akceptującą ,przesłanki inspirowane przekonaniami chrześcijański-

\footnotetext{
${ }^{164}$ Por. Robert C. O'ConNoR, „Nauka przed sądem: analiza racjonalności naturalizmu metodologicznego", przeł. Joanna Popek i Grzegorz Rogula, Filozoficzne Aspekty Genezy 2014, t. 11, s. 106 [95-131], https://tiny.pl/xh8tq (21.10.2018).

${ }^{165}$ Por. O'Connor, „Nauka przed sądem...”, s. 95.

${ }^{166}$ Por. Robert C. O'Connor, „Science on Trial: Exploring the Rationality of Methodological Naturalism", Perspectives on Science and Christian Faith 1997, vol. 49, s. 15 [15-30], https://ti ny.pl/gzlng (21.10.2018).

${ }^{167}$ Eugenie C. Sсотт, Evolution vs. Creationism: An Introduction, 2nd ed., Greenwood Press, Westport, Connecticut, London 2009, s. 56.

${ }^{168}$ Jest to termin McMullina (por. McMuluin, „Odmiany naturalizmu...”, s. 111).

${ }^{169}$ Por. McMuluin, „Odmiany naturalizmu...”, s. 116-127. Na s. 121-127 autor ten omawia trudności związane z akceptacją tego wariantu naturalizmu.

${ }^{170}$ Alvin Plantinga, „When Faith and Reason Clash: Evolution and the Bible”, Christian
} 
mi" $\left.{ }^{171}\right)$, od nauki, która takich przesłanek nie akceptuje.

Można twierdzić, że efektem tych zabiegów będzie pluralizm stanowisk, który może się przyczynić do wzrostu wiedzy. Jeśli jednak zasadniczym celem tych - czego nie da się ukryć — skomplikowanych i wprowadzających sporo zamętu do refleksji nad nauką, decyzji metodologicznych ma być wyłacznie dopuszczenie, w niektórych sytuacjach, wyjaśnień nienaturalistycznych, to kwestia ta znalazła znacznie prostsze rozwiązanie.

$\left(b_{3}\right)$ Trzeci argument $\mathrm{z}$ tej grupy unika powyższych problemów, gdyż proponuje wyraźne i stosowalne zarazem kryterium odstąpienia od wyjaśnień naturalistycznych. Dotychczasowa skuteczność zasady metodologicznego naturalizmu pozwala twierdzić, iż

wyjaśnienia naturalistyczne mają priorytet nad ewentualnymi wyjaśnieniami nienaturalistycznymi, że tylko wtedy z tych pierwszych można zrezygnować, jeśli istnieje ku temu dobry powód. ${ }^{172}$

Powód ten nie jest skutkiem braku wiedzy, lecz uzasadniony jest ,już zdobytą wiedzą". ${ }^{173}$

Ten ostatni argument wspierany jest tezą zwaną ,warunkiem Jodkowskiego". ${ }^{174}$ Warunek ten

domaga się nie dowodu, ale argumentu, czyli rozumowania, które przy bliższym zbadaniu może się okazać błędne. ${ }^{175}$

W myśl omawianego warunku tam, gdzie wprowadza się wyjaśnienia niena-

Scholar's Review 1991, vol. 21, no. 1, s. 30 [8-33], https://tiny.pl/gzln9 (21.10.2018).

${ }^{171}$ McMuluin, „Odmiany naturalizmu...”, s. 121 przyp. 15.

${ }^{172}$ JodKowski, „Rozpoznawanie genezy...”, s. 190-191.

${ }^{173}$ Por. JodKowsKi, Metodologiczne aspekty..., s. 313.

${ }^{174}$ Sprawozdanie z dyskusji nad warunkiem Jodkowskiego przedstawiła Małgorzata GAzDA, „Stephena C. Meyera argument na rzecz projektu w przyrodzie a warunek Jodkowskiego”, Filozoficzne Aspekty Genezy 2015, t. 12, s. 287-292 [287-301], https://tiny.pl/g16k4 (21.10.2018).

${ }^{175}$ Kazimierz JoDKowski, Spór ewolucjonizmu z kreacjonizmem. Podstawowe pojęcia i poglądy, Biblioteka Filozoficznych Aspektów Genezy, t. 1, Wydawnictwo MEGAS, Warszawa 2007, s. 182, https://tiny.pl/qzq8j (21.10.2018). 
turalistyczne, należy wprzódy przedstawić mocną argumentację, zgodnie z którą wyjaśnienia naturalistyczne nie są możliwe. ${ }^{176}$ Argumentacja typu:

żaden [naturalistyczny] mechanizm nigdy nie zostanie odkryty, dzięki czemu pozostanie tylko ta druga alternatywa, ${ }^{177}$

uznawana jest za niewystarczającą (o ile nie zostanie przedstawiony dodatkowy argument, wyjaśniający, dlaczego taki mechanizm nigdy nie zostanie odkryty):

Skutkiem uznania, że $[\ldots]$ został spełniony warunek Jodkowskiego, będzie [...] otrzymanie przepustki do dalszej dyskusji, a nie stwierdzenie słuszności danego argumentu. ${ }^{178}$

Warunek ten rozpoznawany jest w praktyce badawczej ${ }^{179} \mathrm{i}$ przybiera dwie formy: mocniejszą (istnieją podstawy, by wykluczyć wyjaśnienia naturalistyczne) oraz słabszą (istnieją podstawy, by dopuszczać wyjaśnienia nienaturalistyczne).

Rozpocznę od przykładów słabszej postaci warunku Jodkowskiego. W przykładzie pierwszym widoczne jest dopuszczenie wyjaśnień nienaturalistycznych wskutek uznania, że wyjaśnienia naturalistyczne są zbyt mało prawdopodobne:

$\mathrm{Ci}$, którzy przedstawiają empiryczne świadectwa na rzecz ID, nie muszą uzasadniać, że nie jest możliwe wyjaśnienie, które w ogóle nie odwołuje się do wyjaśnień celowych. Muszą oni jedynie uzasadnić, że, w świetle dostępnych danych, jest ono bardzo mało prawdopodobne. ${ }^{180}$

W przykładzie drugim mówi się o istnieniu empirycznych podstaw dla ak-

\footnotetext{
${ }^{176}$ Por. JoDKowsKi, Metodologiczne aspekty..., s. 313; Wojciech SADY, „Dlaczego kreacjonizm «naukowy» nie jest naukowy i dlaczego nie prowadzi do teizmu?", Przeglad Filozoficzny Nowa Seria 2001, nr 1(37), s. 226 [213-228], https://tiny.pl/gdw91 (21.10.2018); JoDKowski, „Ruch kreacjonistyczny...”, s. 246-247; Joркоwsкi, Spór ewolucjonizmu..., s. 182-183.

${ }^{177}$ Por. Pennock, „Bóg w lukach wiedzy...”, s. 170-172.

${ }^{178}$ Gazda, „Stephena C. Meyera...”, s. 287-301. Por. też Stephen C. Meyer, „DNA a pochodzenie życia. Informacja, specyfikacja i wyjaśnienie”, przeł. Dariusz Sagan, Filozoficzne Aspekty Genezy 2005/2006, t. 2/3, s. 212 [133-215], https://tiny.pl/q3m1b (21.10.2018).

${ }^{179}$ Por. JoDKowski, Spór ewolucjonizmu..., s. 182.

${ }^{180}$ NAgEL, „Public Education...”, s. 199-200.
} 
ceptacji niektórych wyjaśnień nienaturalistycznych:

Odkrycie informacji zakodowanej w DNA oraz wielu układów o tzw. nieredukowalnej złożoności, np. złożony układ napędu wici bakterii [...] stawiają pod znakiem zapytania naturalistyczne wyjaśnienia fenomenu życia. ${ }^{181}$

Oto przykłady mocniejszej postaci tego warunku. Pierwszy wyklucza naturalistyczne wyjaśnienia fenomenu wyspecyfikowanej złożoności na podstawie przekonania o niewystarczalności takiego wyjaśnienia:

Sukces programu Dembskiego, poświęconego poszukiwaniu wyspecyfikowanej złożoności w układach biologicznych, zależy od tego, czy jego „ogólny argument na rzecz eliminacji przypadku" [...] jest w stanie objąć - i wyeliminować - ewolucjonistyczne hipotezy wyjaśniające zajście jakiegoś zdarzenia. ${ }^{182}$

Przykład drugi, podobny, mówi o wykluczeniu naturalistycznych wyjaśnień nieredukowalnej złożoności:

materialiści mogą zaakceptować interwencję istot pozaziemskich, gdyby wykazano, że darwinowska teoria ewolucji nie jest w stanie wythumaczyć jakiegoś przypadku złożoności biologicznej. ${ }^{183}$

Przed prezentacją następnych dwóch przykładów wspomnieć należy o tym, że niekiedy jest i tak, iż rozpoznanie podstaw do odrzucenia wyjaśnień naturalistycznych wcale nie prowadzi do decyzji, że należy się z nimi rozstać. Ten stan rzeczy wyjaśnia się w następujący sposób. Filozofowie nauki już dawno temu rozstali się z przekonaniem, w myśl którego do odrzucenia teorii naukowej wystarczy jej niezgodność z faktami. Następnie pojawiło się podejście, wedle któ-

${ }^{181}$ Adam CEnIAN, „Wiara w naukę - jej podstawy, założenia, mocne i słabe strony kultu”, wystąpienie na Konferencji Chrześcijańskiego Forum Pracowników Nauki: Nauka - Etyka Wiara, Rydzyna 30.05-02.06.2013, s. 153 [151-159], https://tiny.pl/gzlns (21.10.2018).

${ }^{182}$ Wesley R. ElsBerry, „«Tańczący z Popperem». Dembski o sprawdzalności”, przeł. Joanna Popek, Filozoficzne Aspekty Genezy 2011, t. 8, s. 187 [179-188], https://tiny.pl/xh81g (21.10. 2018).

${ }^{183}$ Richard Thornhill, „Historyczny związek między darwinizmem a argumentem z biologicznego projektu”, przeł. Anna Droś, Natalia Górska, Mateusz Krzyżanowski, Renata Merda, Zofia Sadowska i Dariusz Sagan, Filozoficzne Aspekty Genezy 2012, t. 9 , s. 95 [79-105], https://ti ny.pl/gzlnb (21.10.2018). 
rego proces odrzucania jest bardziej skomplikowany, a poprawne ujęcie relacji teoria-doświadczenie ma charakter trójczłonowy: teoria - teoria alternatywna — sprawdzian empiryczny.

Badania EUO doprowadziły do przekonania, że związek między teorią a doświadczeniem może być bardziej skomplikowany niż sugerują to zastane rozwiązania problemu. ${ }^{184}$ Analizy kontrowersji kreacjonizm-ewolucjonizm pokazały, że w niektórych przynajmniej przypadkach poprawne ujęcie relacji teoriadoświadczenie ma charakter czteroczłonowy: teoria - teoria alternatywna przyjęty EUO — sprawdzian empiryczny:

Spór ewolucjonizm-kreacjonizm pokazuje, że [...] nawet jeśli fakty przemawiają przeciwko jakiejśs teorii i istnieje alternatywna teoria, która z tymi faktami jest zgodna, to nie wystarczy to do eliminacji tej pierwszej w przypadku, gdy pasuje ona do przyjętej perspektywy filozoficzno-teologicznej (epistemicznego układu odniesienia), a jej rywalka jest $\mathrm{z}$ tą perspektywą niezgodna. ${ }^{185}$

Presja powszechnie przyjmowanego EUO może zneutralizować dowolną trudność teorii, która ten EUO akceptuje.

Oto pierwszy z tych przykładów:

Michael Behe [...] mówi, że bez względu na to, co jeszcze ewolucjonizm darwinowski może skutecznie wyjaśnić, nie jest w stanie wytłumaczyć biochemicznej złożoności żywej komórki. ${ }^{186}$

\footnotetext{
${ }^{184}$ Por. w tej sprawie wypowiedź Kiliana w: Bylica, Gazda, JodKowski, Kilian i SAGan, „Dyskusja nad artykułem Adama Trybusa...”, s. 8-9.

${ }^{185}$ Kazimierz JoDKowsKI, „Eskapizm teologii i filozofii katolickiej w sprawie «nauka a religia»", Na Poczatku... 2005, nr 7-8 (196-197), s. 273-284 [261-284], https://tiny.pl/gztl8 (21.10. 2018). Por. też Kazimierz Jodkowski, „Filozofia przyrody a nauki przyrodnicze”, Colloquia Communia 2007, nr 1-2 (82-83), s. 21-22 [15-22].

Mówi się tu ogólnie o perspektywie filozoficzno-teologicznej, bowiem wszystkie dotychczas przebadane EUO (naturalistyczne, nadnaturalistyczne i artyficjalistyczne) ją posiadają. Przekonanie takie, gdy zostanie odniesione do nadnaturalistycznego czy artyficjalistycznego EUO nie budzi żadnych wątpliwości. Jednak naturalistyczny EUO również można charakteryzować w ten sposób. Elementarne twierdzenie tego ostatniego EUO, w myśl którego albo Boga nie ma, albo jeśli jest, to nie działa w sposób empirycznie wykrywalny w przyrodzie, ma charakter filozoficzno-teologiczny. Naturalistyczny EUO jest „teologią negatywną, a więc czymś w rodzaju religii” (Jodkowski, „Twarde jądro...”, s. 109).

${ }^{186}$ Kenneth R. Miller, „Odpowiedź na biochemiczny argument z projektu”, przeł. Dariusz
} 
Dla tak sformułowanej tezy zaproponowano kontrargument opierający się na tezie o niekompletności danych. Wynika $\mathrm{z}$ niego, że mimo tego iż nie są możliwe wyjaśnienia naturalistyczne, to i tak należy preferować naturalizm:

wiele z jego [Behe'ego] przykładów nigdy nie znajdzie ostatecznego naturalistycznego wyjaśnienia $\mathrm{z}$ tego prostego powodu, że ścieżki prowadzące do tych struktur zostały pogrzebane w ciągu dwóch do trzech i pół miliarda lat ewolucji. ${ }^{187}$

Drugi przykład:

Biolodzy muszą [...] zmierzyć się z problemem: czy systemy nieredukowalnie złożone wskazują na ewolucyjną lukę, której nie da się zapełnić? Jeśli tak, to darwinizm kroczy po złej drodze, a Behe dokonał zdumiewającego odkrycia. ${ }^{188}$

I tym razem pojawia się przekonanie, zgodnie z którym brak naturalistycznych wyjaśnień nie podważa naturalizmu:

nie mamy żadnej gwarancji, że możemy zrekonstruować historię jakiegoś procesu biochemicznego. Ale nawet jeśli jest to niemożliwe, to nieredukowalna złożoność tego procesu nie świadczy przeciwko gradualnej ewolucji. ${ }^{189}$

Podsumowując, zauważyć należy, że warunek Jodkowskiego jest praktycznym zastosowaniem Feyerabendowskiego przekonania o wzajemnym oddziaływaniu zasad proliferacji i uporczywości. Dwa ostatnie przykłady pokazują też jasno, że zaangażowanie w przyjętą perspektywę filozoficzno-teologiczną jest w stanie zneutralizować każdą trudność, z którą boryka się uwikłana w tę perspektywę teoria. Pomimo tego warunek Jodkowskiego jest też, przynajmniej na chwilę obecną, jedynym dającym się stosować i już stosowanym uzasadnieniem odstępowania od wyjaśnień naturalistycznych.

Sagan, Filozoficzne Aspekty Genezy 2005/2006, t. 2/3, s. 98 [97-119], https://tiny.pl/qzq81 (21.10. 2018). Por. też Mark Perakh, „Nieredukowalna sprzeczność”, przeł. Dariusz Sagan, Filozoficzne Aspekty Genezy 2004, t. 1, s. 83-84 [71-113], https://tiny.pl/xh8pl (21.10.2018).

${ }^{187}$ William B. Provine, „Projekt? Tak! Ale czy inteligentny?”, przeł. Sławomir Piechaczek, Filozoficzne Aspekty Genezy 2005/2006, t. 2/3, s. 233 [217-237], https://tiny.pl/xh8rs $(21.10$ 2018).

${ }^{188}$ H. Allen OrR, „Ponownie darwinizm kontra inteligentny projekt”, przeł. Dariusz Sagan, Filozoficzne Aspekty Genezy 2004, t. 1, s. 39 [33-48], https://tiny.pl/gzlkt (21.10.2018).

${ }^{189}$ OrR, „Ponownie darwinizm...”, s. 41. 


\section{Uwagi końcowe}

W niniejszym artykule omówiłem ważniejsze argumenty na rzecz naturalizmu metodologicznego. Argumenty te podzielone zostały ze względu na to, czy $\mathrm{w}$ ich ramach dopuszczalne są rewizje naturalizmu metodologicznego, czy też nie. Następnie podzielone zostały ze względu na to, czy zawierają konkretne warunki utrzymywania naturalizmu albo jego porzucenia, czy też takich warunków nie podają.

W ramach podejścia, które nie dopuszcza rewizji, omówiłem następujące grupy argumentów: (a) „nie, bo nie”; (b) w imię zasady uporczywości należy obstawać przy naturalizmie; (c) naturalizm jest definicyjnym składnikiem pojęcia nauki; (d) naturalizm tworzy skuteczną tradycję uprawiania nauki; (e) naturalizm zagwarantować ma środowisku naukowemu największy z możliwych konsensus; (f) naturalizm jest formą brzytwy Ockhama; (g) dopuszczenie wyjaśnień nienaturalistycznych ma szkodliwe następstwa dla uprawiania nauki.

Analizy przedstawionych tu argumentów na rzecz naturalizmu metodologicznego pozwalają uznać tezę, że żaden z omówionych argumentów na rzecz naturalizmu metodologicznego nie daje podstaw po temu, by decyzja odrzucania wyjaśnień nienaturalistycznych mogła być bezapelacyjnie uznana za kamień węgielny współczesnej nauki. Ani znane fakty, ani rozumowania nie stanowią nieodpartych racji na rzecz naturalizmu metodologicznego.

W ramach podejścia dopuszczającego rewizję naturalizmu omówiłem dwie grupy argumentów. Jedna z nich nie podaje konkretnych warunków odstąpienia od wyjaśnień naturalistycznych. Druga warunki takie formułuje. Omówieniu drugiej grupy towarzyszyła analiza trzech procedur odstępowania. Pierwsza procedura $\mathrm{z}$ tej grupy opiera się na metodologicznej decyzji rozszerzenia zakresu terminów „nauka” i „wiedza”. Jak pokazałem, prowadzi ona do akceptacji innych, skomplikowanych i wprowadzających sporo zamętu do refleksji nad nauką, decyzji metodologicznych. Druga procedura odwołuje się do „przytłaczających i niewątpliwych" świadectw empirycznych, które miałyby podważać wyjaśnienia naturalistyczne. Jednakże żadne świadectwa wzięte w izolacji nie są ani przytłaczające, ani niewątpliwe. O randze danego świadectwa świadczy uprzednio przyjęta perspektywa teoretyczna. 
Trzecia procedura $\mathrm{z}$ tej grupy unika powyższych problemów. W zamian proponuje wyraźne i stosowalne zarazem kryterium odstąpienia od wyjaśnień naturalistycznych. Mam tu na myśli warunek Jodkowskiego - takie kryterium odstąpienia od tych wyjaśnień, które nie bazuje na braku wiedzy, lecz uzasadniane jest aktualnie posiadaną wiedzą. Wskazałem na przykładach realizacji tego warunku, że przybiera on dwie postaci: słabszą (istnieją podstawy, by dopuszczać wyjaśnienia nienaturalistyczne) i mocniejszą (istnieją podstawy, by wykluczać wyjaśnienia naturalistyczne).

Krzysztof J. Kilian

\section{Bibliografia}

Andersson Gunnar, Criticism and the History of Science: Kuhn's, Lakatos's, and Feyerabend's Criticism of Critical Rationalism, E.J. Brill, Leiden - New York - Köln 1994.

Ayala Francisco J., „Darwin's Revolution”, w: CAmpbell and Schoff (eds.), Creative Evolution..., s. 1-18.

Bartlett Jonathan and Holloway Eric, „Introduction”, w: Bartlett and Holloway (eds.), Naturalism and Its Alternatives..., s. 1-9.

Bartlett Jonathan and Holloway Eric (eds.), Naturalism and Its Alternatives in Scientific Methodologies: Proceedings of the $\mathbf{2 0 1 6}$ Conference on Alternatives to Methodological Naturalism, Blyth Institute Press, Broken Arrow, Oklahoma 2017.

BeCKwith Francis J., „How To Be an Anti-Intelligent Design Advocate”, University of St Thomas Journal of Law \& Public Policy 2009, vol. 4, no. 1, s. 35-65, https://tiny.pl/gzpcg (20.10.2018).

BeHe Michael J., Czarna skrzynka Darwina. Biochemiczne wyzwanie dla ewolucjonizmu, przeł. Dariusz Sagan, Biblioteka Filozoficznych Aspektów Genezy, t. 4, Wydawnictwo MEGAS, Warszawa 2008.

BEHE Michael J., „Filozoficzne zarzuty stawiane hipotezie inteligentnego projektu: odpowiedź na krytykę", przeł. Dariusz Sagan, Filozoficzne Aspekty Genezy 2004, t. 1, s. 115139, https://tiny.pl/gt9nw (19.10.2018).

BeHE Michael J., „Nieredukowalna złożoność: problem dla ewolucjonizmu darwinowskiego”, przeł. Dariusz Sagan, Filozoficzne Aspekty Genezy 2005/2006, t. 2/3, s. 115-139, https: //tiny.pl/gt9nw (19.10.2018). 
Borczyк Bartosz, Chmielewski Adam, Elżanowski Andrzej, Jodkowski Kazimierz, LeszCZyŃski Damian, Lukierski Jerzy, Nysler Łukasz i PAwŁowski Bogusław, „Dyskusja”, w: LESZCZYŃSKI (red.), Ewolucja. Filozofia. Religia..., s. 155-172, https://tiny.pl/xh8gj (20.10. 2018).

Boudry Maarten, Blancke Stefaan, and Braeckman Johan, „How Not to Attack Intelligent Design Creationism: Philosophical Misconceptions About Methodological Naturalism”, Foundations of Science 2010, vol. 15, no. 3, s. 227-244, https://tiny.pl/gzl4j (21.10.2018).

BRAND Leonard, „Naturalizm i jego rola w nauce”, przeł. Paulina Korzeniewska-Nowakowska, Filozoficzne Aspekty Genezy 2016, t. 13, s. 49-74, https://tiny.pl/g2sg3 (19.10.2018).

Bugajak Grzegorz, „Naturalizm nauki a działanie Boga w świecie”, w: Mączka i URbańCZYK (red.), Teologia nauki..., s. 145-172.

Bugajak Grzegorz i Tомсzyк Jacek (red.), Kontrowersje wokól początków czlowieka, Księgarnia św. Jacka, Katowice 2007.

ByLICA Piotr, „Główne założenia i problemy teizmu naturalistycznego w sprawie relacji sfery nadprzyrodzonej i świata przyrodniczego", w: Dyk (red.), Sozologia systemowa. Tom IV..., s. 55-95, https://tiny.pl/q3m1d (19.10.2018).

BYLICA Piotr, „Kazimierza Jodkowskiego koncepcja epistemicznych układów odniesienia a teizm naturalistyczny Johna Polkinghorne'a", w: Bylica, Kilian, Piotrowski i Sagan (red.), Filozofia - nauka — religia..., s. 191-211, http://tiny.pl/g8h4z (18.10.2018).

Bylica Piotr, „Konflikt między teizmem i nauką bazującą na naturalizmie - w ujęciu Phillipa E. Johnsona", Zagadnienia Naukoznawstwa 2003, nr 3-4 (157-158), s. 227-238, https://tiny.pl/xh894 (19.10.2018).

BYLICA Piotr, „Nauka światopoglądowo neutralna?”, Fronda 2012, nr 63, s. 67-80, https://ti ny.pl/gkfxr (20.10.2018).

BYLICA Piotr, „Spór o naukowość teorii inteligentnego projektu”, w: JoDKOwSKI (red.), Teoria inteligentnego projektu..., s. 51-78, https://tiny.pl/qzq8f (20.10.2018).

BYLICA Piotr, „Testowalność teorii inteligentnego projektu”, Filozofia Nauki 2003, r. 9, nr 2(42), s. 41-49, https://tiny.pl/q3m11 (19.10.2018).

ByLICA Piotr, Współczesny teizm naturalistyczny z punktu widzenia modelu poziomów analizy. Problem dzialania sfery nadnaturalnej w przyrodzie, Biblioteka Filozoficznych Aspektów Genezy, t. 7, Instytut Filozofii Uniwersytetu Zielonogórskiego, Zielona Góra 2016, http://tiny.pl/gkdv1 (16.10.2018).

ByLICA Piotr, „Zarys modelu poziomów analizy w badaniach relacji nauki i religii”, Filozoficzne Aspekty Genezy 2012, t. 9, s. 221-253, https://tiny.pl/xhzml (21.10.2018).

Bylica Piotr, Gazda Małgorzata, Jodkowski Kazimierz, Kilian Krzysztof J. i Sagan Dariusz, „Dyskusja nad artykułem Adama Trybusa «Program badawczy SETI a teoria inteli- 
gentnego projektu»", Filozoficzne Aspekty Genezy 2016, t. 13, s. 211-242, https://tiny.pl/ g8nvh (19.10.2018).

Bylica Piotr, JodKowski Kazimierz, Kilian Krzysztof J. i SAgan Dariusz, „Dyskusja nad artykułem Adama Groblera, «Słabości eksplanacyjne teorii inteligentnego projektu»”, Filozoficzne Aspekty Genezy 2013, t. 10, s. 17-63, https://tiny.pl/q3m1m (15.10.2018).

Bylica Piotr, Kilian Krzysztof J., Piotrowski Robert i Sagan Dariusz (red.), Filozofia nauka - religia. Ksiega jubileuszowa dedykowana Profesorowi Kazimierzowi Jodkowskiemu z okazji 40-lecia pracy naukowej, Oficyna Wydawnicza Uniwersytetu Zielonogórskiego, Zielona Góra 2015.

Bylica Piotr and Sagan Dariusz, „God, Design, and Naturalism: Implications of Methodological Naturalism in Science for Science-Religion Relation", Pensamiento 2008, vol. 64, núm. 242, s. 621-638, https://tiny.pl/g2884 (20.10.2018).

Campbell John H. and Schoff J.W. (eds.), Creative Evolution!?, Jones and Bartlett, New York 1994.

CeniAn Adam, „Wiara w naukę - jej podstawy, założenia, mocne i słabe strony kultu”, wystąpienie na Konferencji Chrześcijańskiego Forum Pracowników Nauki: Nauka - Etyka - Wiara, Rydzyna 30.05-02.06.2013, s. 151-159, https:/tiny.pl/gzlns (21.10.2018).

Chateaubriand Oswaldo, „Ockham's Razor”, O Que Nos Faz Pensa 1990, no. 3, s. 51-75, https://tiny.pl/gzpfr (20.10.2018).

Clarke Steve, „Naturalism, Science and the Supernatural”, Sophia. International Journal of Philosophy and Traditions 2009, vol. 48, s. 127-142.

Cohen Robert S. and Wartofsky Marx W. (eds.), Proceedings of the Boston Colloquium for the Philosophy of Science, 1964/1966. In Memory of Norwood Russell Hanson, Boston Studies in the Philosophy of Science, vol. 3, D. Reidel Publishing Company, Dordrecht 1967.

Colodny Robert G. (ed.), Beyond the Edge of Certainty: Essays in Contemporary Science and Philosophy, Prentice-Hall, Englewood Cliffs, New Jersey 1965.

CoYNe Jerry A., Ewolucja jest faktem, przeł. Marcin Ryszkiewicz i Wiesław Studencki, Prószyński i S-ka, Warszawa 2009.

Coyne Jerry A., „Science, Religion, and Society: The Problem of Evolution in America”, Evolution. International Journal of Organic Evolution 2012, vol. 66, no. 8, s. 2654-2663, https://tiny.pl/gzj81 (20.10.2018).

Coyne SJ George V., „Przypadek jako metoda Boskiego stwarzania”, przeł. Dariusz Sagan, Filozoficzne Aspekty Genezy 2005/2006, t. 2/3, s. 39-44, https://tiny.pl/xhkgd (19.10.2018).

CRomBIE Alistair C. (ed.), Scientific Change: Historical Studies in the Intellectual, Social and Technical Conditions for Scientific Discovery and Technical Invention, from An- 
tiquity to the Present, Symposium on the History of Science, University of Oxford 915 July 1961, Heinemann, London 1963.

Cuberbiller Marta, „O metodach datowania radioaktywnego”, w: Gazda (red.), Idź Pod Prąd..., s. 230-233, https://tiny.pl/gzj77 (19.10.2018).

Curthoys Jean and Suchting Wal, „Feyerabend's Discourse Against Method: A Marxist Critique", Inquiry 1977, vol. 20, no. 2-3, s. 243-397.

DArwin Karol, Autobiografia i wybór listów. Dzieła wybrane, t. 8, przeł. A. Iwanowska, A. Krasicka, J. Połtowicz i S. Skowron, Państwowe Wydawnictwo Rolnicze i Leśne, Warszawa 1960.

DARWIN Karol, O powstawaniu gatunków drogą doboru naturalnego, czyli o utrzymaniu się doskonalszych ras w walce o byt. Dzieła wybrane, t. 2, przeł. Szymon Dickstein i Józef Nusbaum, Państwowe Wydawnictwo Rolnicze i Leśne, Warszawa 1959.

DAwKINS Richard, Ślepy zegarmistrz, czyli jak ewolucja dowodzi, że świat nie został zaplanowany, przeł. Antoni Hoffman, Biblioteka Myśli Współczesnej, Państwowy Instytut Wydawniczy, Warszawa 1994.

Delfino Robert A., „Naturalizm metodologiczny i ewolucja”, przeł. Rafał Lizut, w: JAROSZYŃSKI (red.), Ewolucjonizm czy kreacjonizm..., s. 137-156, https://tiny.pl/gzj7b (19.10. 2018).

Dembski William A., „Becoming a Disciplined Science: Prospects, Pitfalls, and Reality Check for ID”, https://tiny.pl/gzpct (20.10.2018).

Dembski William A., „Odmiany naturalizmu. Czy któraś forma naturalizmu jest zgodna z teorią inteligentnego projektu?", przeł. Dariusz Sagan, Na Początku... 2005, nr 1-2, s. 45 54, https://tiny.pl/xhkg8 (19.10.2018).

Dembski William A., „Śmierć i Upadek: dlaczego teistyczny ewolucjonizm nie łagodzi problemu zła", przeł. Dariusz Sagan, Filozoficzne Aspekty Genezy 2013, t. 10, s. 159-176, https ://tiny.pl/xh2nj (19.10.2018).

Dembski William A., The Design Revolution: Answering the Toughest Questions about Intelligent Design, InterVarsity Press, Downers Grove 2004.

Dębowski Józef i Starzyńska-Kościuszko Ewa (red.), Nauka. Racjonalność. Realizm. Między filozofią przyrody a filozofią nauki i socjologią wiedzy, Instytut Filozofii Uniwersytetu Warmińsko-Mazurskiego w Olsztynie, Olsztyn 2013.

Dose Klaus, „The Origin of Life: More Questions Than Answers”, Interdisciplinary Science Reviews 1988, vol. 13, no. 4, s. 348-356.

Dudek Joanna i Konstańczak Stefan (red.), Homo moralis - homo creativus. Prace dedykowane Profesorom Zdzisławowi Kalicie i Krzysztofowi Kaszyńskiemu, Oficyna Wydawnicza Uniwersytetu Zielonogórskiego, Zielona Góra 2015. 
Dүк Wiesław (red.), Sozologia systemowa. Tom IV. Biosfera. Czlowiek i jego środowisko w aspekcie przyrodniczym, filozoficznym i teologicznym, Wydawnictwo Naukowe Uniwersytetu Szczecińskiego, Szczecin 2012.

Einstern Albert, The World As I See It, London 1949.

EldRedge Niles, The Monkey Business: A Scientist Looks at Creationism, Washington Square Press, New York 1982.

ElDREDGE Niles, The Triumph of Evolution and the Failure of Creationism, W.H. Freeman and Company, New York 2001.

ELSBERRY Wesley R., „«Tańczący z Popperem». Dembski o sprawdzalności”, przeł. Joanna Popek, Filozoficzne Aspekty Genezy 2011, t. 8, s. 179-188, https://tiny.pl/xh81g (21.10. 2018).

Ferngren Gary B. (ed.), History of Science and Religion in the Western Tradition. An Encyclopedia, Garland Publishing, Inc., New York \& London 2000.

Feyerabend Paul K., Against Method: Outline of an Anarchistic Theory of Knowledge, Verso, London 1975.

Feyerabend Paul K., „Dialectical Materialism and the Quantum Theory”, Slavic Review 1966, vol. 25, no. 3, s. 414-417.

Feyerabend Paul K., Dialogi o wiedzy, przeł. Justyna Nowotniak, Fundacja Aletheia, Warszawa 1999.

Feyerabend Paul K., „Fantazje platońskie”, w: Feyerabend, Dialogi o wiedzy..., s. 5-76.

Feyerabend Paul K., Farewell to Reason, Verso, New York 1996.

FeYERABEND Paul K., Jak być dobrym empirystą, przeł. Krystyna Zamiara, Państwowe Wydawnictwo Naukowe, Warszawa 1979.

Feyerabend Paul K., „Jak być dobrym empirystą? Wezwanie do tolerancji w kwestiach epistemologicznych", w: FEYERABEND, Jak być dobrym empirystą..., s. 23-61.

Feyerabend Paul K., „Ku pocieszeniu specjalisty”, w: Feyerabend, Jak być dobrym empirystą..., s. 200-250.

Feyerabend Paul K., „Linguistic Arguments and Scientific Method”, w: Feyerabend, Philosophical Papers. Vol. 1..., s. 146-160.

Feyerabend Paul K., „Mit «Nauki» i jego rola w społeczeństwie”, przeł. Janusz Jusiak, w: JoDKowsKi (red.), Czy sprzeczność może być racjonalna..., s. 292-307, https://tiny.pl/gz5 b1 (18.10.2018).

Feyerabend Paul K., „On the Improvement of the Sciences and the Arts and the Possible Identity of the Two", w: Cohen and Wartofsky (eds.), Proceedings..., s. 387-415. 
Feyerabend Paul K., „Outline of a Pluralistic Theory of Knowledge and Action”, w: FeyerABEND, Philosophical Papers. Vol. 3..., s. 104-111.

Feyerabend Paul K., Philosophical Papers. Vol. 1. Realism, Rationalism \& Scientific Method, Cambridge University Press, Cambridge - New York — Portchester — Melbourne - Sydney 1981.

Feyerabend Paul K., Philosophical Papers. Vol. 3. Knowledge, Science and Relativism, Cambridge University Press, Cambridge 1999.

Feyerabend Paul K., „Podsumowująca niefilozoficzna leśna przechadzka”, w: FeYerabend, Dialogi o wiedzy..., s. 77-142.

Feyerabend Paul K., „Preface to the Second Edition”, w: Feyerabend, Farewell to Reason..., s. v-viii.

Feyerabend Paul K., „Problems of Empiricism”, w: Colodny (ed.), Beyond the Edge of Certainty..., s. 145-260.

Feyerabend Paul K., Przeciw metodzie, przeł. Stefan Wiertlewski, Wydawnictwo Siedmioróg, Wrocław 1996.

Feyerabend Paul K., „«Racjonalność» badania”, przeł. Zdzisław Kowalski, w: JodKowsKi (red.), Czy sprzeczność może być racjonalna..., s. 271-289.

FEYERABEND Paul K., „Realizm i instrumentalizm. Uwagi o logice potwierdzania przez fakty”, w: FeYERABEND, Jak być dobrym empirystą..., s. 152-193.

Feyerabend Paul K., The Tyranny of Science, Polity Press, Cambridge UK - Malden USA 2012.

Feyerabend Paul K., „Wyjaśnianie, redukcja i empiryzm”, w: Feyerabend, Jak być dobrym empirystą..., s. 62-151.

Feyerabend Paul K., Zabijanie czasu, przeł. Tomasz Bieroń, Wydawnictwo Znak, Kraków 1996.

Frank Phillip G., The Validation of Scientific Theories, The Beacon Press, Boston 1956.

FRANK Phillip G., „The Variety of Reasons for the Acceptance of Scientific Theories”, w: Frank, The Validation of Scientific Theories..., s. 3-28.

Fuchs Stephan and SPEAR Joseph H., „The Social Conditions of Cumulation”, The American Sociologist 1999, vol. 30, no. 2, s. 1-40.

Futuyma Douglas J., „Cuda a molekuły”, przeł. Dariusz Sagan, Filozoficzne Aspekty Genezy 2004, t. 1, s. 65-69, https://tiny.pl/xhzmf (21.10.2018).

GAzDa Małgorzata (red.), Idź Pod Prąd w sporze ewolucjonizm-kreacjonizm, Wydawnictwo POD PRĄD, Lublin 2017. 
GazDA Małgorzata, „Stephena C. Meyera argument na rzecz projektu w przyrodzie a warunek Jodkowskiego", Filozoficzne Aspekty Genezy 2015, t. 12, s. 287-301, https://tiny.pl/g16 k4 (21.10.2018).

GiLson Tom, „Naturalizm metodologiczny, teizm metodologiczny i regularyzm”, przeł. Dariusz Sagan, Filozoficzne Aspekty Genezy 2017, t. 14, s. 89-98, https://tiny.pl/gz879 (21.10. 2018).

Gould Stephen J., „Ewolucja jako fakt i teoria”, w: Gould, Niewczesny pogrzeb Darwina..., s. 129-140.

Gould Stephen J., Niewczesny pogrzeb Darwina. Wybór esejów, przeł. Nina KancewiczHoffman, Biblioteka Myśli Wspótczesnej, Państwowy Instytut Wydawniczy, Warszawa 1991.

Grizzle Raymond E., „Some Comments on the «Godless» Nature of Darwinian Evolution, And a Plea to the Philosophers Among Us", Perspectives on Science and Christian Faith 1992, vol. 43, s. 175-177, https://tiny.pl/gzj7d (19.10.2018).

Grobler Adam, „Słabości eksplanacyjne teorii inteligentnego projektu”, Filozoficzne Aspekty Genezy 2013, t. 10, s. 7-16, https://tiny.pl/xh8ls (20.10.2018).

Harold Franklin M., The Way of the Cell: Molecules, Organisms, and the Order of Life, Oxford University Press, Oxford 2001.

Hartnett John G., „,The Problem with Science Is That So Much of It Simply Isn't”, Journal of Creation 2017, vol. 13, no. 2, s. 6-7.

Heller Michał, „Nie za bardzo inteligentny projekt”, Copernicus Center 24 grudnia 2014, https://tiny.pl/gzj65 (20.10.2018).

Heller Michał, Sens życia i sens Wszechświata. Studia z teologii wspólczesnej, Biblos, Tarnów 2002.

HILBERT Martin, „Darwinowskie podziały. Papież, kardynał, jezuita i ewoluująca debata nad pochodzeniem”, przeł. Dariusz Sagan, Filozoficzne Aspekty Genezy 2005/2006, t. 2/3, s. 45-63, https://tiny.pl/gzj8m (20.10.2018).

Hoffman Antoni, „Wstęp”, w: Dawkins, Ślepy zegarmistrz..., s. 5-10.

IsAaC Randy, „Assessing the RATE Project”, Perspectives on Science and Christian Faith 2007, vol. 59, no. 2, s. 143-146, https://tiny.pl/gzj7g (19.10.2018).

Janeczer Stanisław, Starościc Anna, DąbeK Dariusz i Herda Justyna (red.), Filozofia przyrody, Dydaktyka Filozofii, t. III, Wydawnictwo Katolickiego Uniwersytetu Lubelskiego, Lublin 2013.

JARoszyv́ski Piotr (red.), Ewolucjonizm czy kreacjonizm, Przyszlość Cywilizacji Zachodu, Fundacja „Lubelska Szkoła Filozofii Chrześcijańskiej”, Lublin 2008. 
JoDKошsкı Kazimierz, „Antynaturalizm teorii inteligentnego projektu”, Roczniki Filozoficzne 2006, t. 54, nr 2, s. 63-76, http://tiny.pl/qzq86 (12.10.2018).

Jodкоwsкı Kazimierz, „Curriculum Vitae”, http://tiny.pl/gkfxf (18.10.2018).

Jodкошsкi Kazimierz (red.), Czy sprzeczność może być racjonalna?, Realizm. Racjonalność. Relatywizm, t. 4, Wydawnictwo UMCS, Lublin 1986.

JoDкошsк Kazimierz, „Czy teoria inteligentnego projektu posiada konsekwencje, dotyczące istnienia nadnaturalnego projektanta? Polemika z Elliottem Soberem", Filozoficzne Aspekty Genezy 2007/2008, t. 6/7, s. 41-49, https://tiny.pl/qzq85 (20.10.2018).

JoDKowski Kazimierz, „,Darwinowska teoria ewolucji jako teoria filozoficzna”, w: KonstaŃCZAK i TURowSKI (red.), Filozofia jako mądrość bycia..., s. 17-23, https://tiny.pl/q3m56 (21.10.2018).

JoDKowskı Kazimierz, „Epistemiczne układy odniesienia i «warunek Jodkowskiego»”, w: LataWiec i BugajaK (red.), Filozoficzne i naukowo-przyrodnicze elementy..., s. 108-123, http://tiny.pl/g28sn (15.10.2018).

JoDKowski Kazimierz, „Eskapizm teologii i filozofii katolickiej w sprawie «nauka a religia»", Na Poczatku ... 2005, nr 7-8 (196-197), s. 261-284, https://tiny.pl/gztl8 (21.10.2018).

JoDкоwsкi Kazimierz, „Filozofia nauki Paula K. Feyerabenda. Stadium umiarkowane”, Studia Filozoficzne 1979, $\mathrm{nr}$ 11(168), s. 59-75.

Jodкowski Kazimierz, „Filozofia przyrody a nauki przyrodnicze”, Colloquia Communia 2007, nr 1-2 (82-83), s. 15-22.

JoDKowsкı Kazimierz, „Filozoficzna natura sporu ewolucjonizm-kreacjonizm. Refleksje po lekturze tekstu Phillipa E. Johnsona”, Na Początku... 2000, nr 7-8 (131-132), s. 211-217, https://tiny.pl/gzpcc (20.10.2018).

JoDKошsкi Kazimierz, „Interpretacje Kuhnowskiej tezy o niewspółmierności”, Roczniki Filozoficzne 1984, t. 32, z. 3, s. 173-198, https://tiny.pl/gzpcj (20.10.2018).

JoDKowski Kazimierz, „Kłopoty teistycznego ewolucjonizmu”, w: BugaJaK i TomczyK (red.), Kontrowersje..., s. 209-224, https://tiny.pl/xhkgl (19.10.2018).

Jоркоwsкı Kazimierz, „Kreacjonizm a naturalizm nauk przyrodniczych”, Annales Universitatis Mariae Curie-Sklodowska, Sectio I, Lublin-Polonia 1996/1997, vol. 21-22, s. 11-26, https://tiny.pl/gplq8 (19.10.2018).

JoDKowski Kazimierz, „Metafizyczne opowieści nauki jako fundament pluralizmu naukowego", w: Johnson, Wielka metafizyczna opowieść nauki..., s. 74-85, http://tiny.pl/q3m $5 \mathrm{p}(18.10 .2018)$.

JoDKоWSKI Kazimierz, Metodologiczne aspekty kontrowersji ewolucjonizm-kreacjonizm, Realizm. Racjonalność. Relatywizm, t. 35, Wydawnictwo UMCS, Lublin 1998. 
Jоркошsкі Kazimierz (red.), Na czym polega racjonalność nauki?, Realizm. Racjonalność. Relatywizm, t. 7, Wydawnictwo UMCS, Lublin 1991.

JoDкоwsкi Kazimierz, „Naturalizm ewolucjonizmu a wiara religijna. Przypadek Darwina”, Przeglad Religioznawczy 1999, nr 1(191), s. 17-34, https://tiny.pl/q3m5c (20.10.2018).

Joркоwsкı Kazimierz, „Nauka w oczach Feyerabenda”, w: Jodкоwsкi (red.), Czy sprzeczność może być racjonalna..., s. 227-270.

JodKowski Kazimierz, „Nienaukowy fundament nauki”, w: PIETRZAK (red.), Granice nauki..., s. 59-108, http://tiny.pl/q3mlq (15.10.2018).

JoDKошsкi Kazimierz, „Od krytycznego racjonalizmu do anarchizmu metodologicznego”, w: Zachariasz (red.), Profile racjonalności..., s. 135-158.

JoDкоwsкi Kazimierz, „Przedmowa”, Filozoficzne Aspekty Genezy 2004, t. 1, s. 5-6, http:// tiny.pl/g8kn6 (02.10.2018).

JoDKowski Kazimierz, „Radykalna epistemologia”, Studia Filozoficzne 1984, nr 11-12, s. 179-187, https://tiny.pl/gz5z1 (18.10.2018).

JodKowski Kazimierz, „Rozpoznawanie genezy: istota sporu ewolucjonizm-kreacjonizm”, Roczniki Filozoficzne 2002, t. 50, z. 3, s. 187-198, http://tiny.pl/xh2bp (11.10.2018).

JoDKоwsкi Kazimierz, „Ruch kreacjonistyczny jest elementem pluralizmu naukowego”, Przeglad Filozoficzny - Nowa Seria 2001, R. X, nr 1(37), s. 241-253, https://tiny.pl/gdw 95 (20.10.2018).

Jоркошsкі Kazimierz, „Spisek Darwina”, w: LeszczyŃski (red.), Ewolucja. Filozofia. Religia..., s. 265-227, https://tiny.pl/q3m53 (21.10.2018).

JoDKowsKi Kazimierz, Spór ewolucjonizmu z kreacjonizmem. Podstawowe pojęcia i poglądy, Biblioteka Filozoficznych Aspektów Genezy, t. 1, Wydawnictwo MEGAS, Warszawa 2007, https://tiny.pl/qzq8j (21.10.2018).

JoDкошऽкі Kazimierz (red.), Teoria inteligentnego projektu - nowe rozumienie naukowości?, Biblioteka Filozoficznych Aspektów Genezy, t. 2, Wydawnictwo MEGAS, Warszawa 2007.

JoDкоwsкi Kazimierz, „Twarde jądro ewolucjonizmu”, Roczniki Filozoficzne 2003, t. 51, z. 3, s. 77-117, https://tiny.pl/q3m5j (19.10.2018).

JoDKоwsкi Kazimierz, „Uczony w ciemnym budynku. Na marginesie metafory Elżbiety Kałuszyńskiej”, w: Dębowski i StarzyńsKa-Kościuszko (red.), Nauka. Racjonalność. Realizm..., s. 55-67, https://tiny.pl/q3m1x (18.10.2018).

JoDKowski Kazimierz, „W poszukiwaniu twardego jądra ewolucjonizmu”, Filozofia Nauki 2001, nr 2(34), s. 7-18, https://tiny.pl/xh81h (21.10.2018). 
JODKOWSKI Kazimierz, Wspólnoty uczonych, paradygmaty i rewolucje naukowe, $R$ ealizm. Racjonalność. Relatywizm, t. 22, Wydawnictwo UMCS, Lublin 1990.

Jodkowski Kazimierz, „«Wszystko ujdzie». Anarchizm epistemologiczny Paula K. Feyerabenda", Akcent 1982, nr 2(8), s. 127-134.

JoDKowski Kazimierz i KILIAN Krzysztof J., „Feyerabendowskie rozwiązanie problemu psychofizycznego", w: Dүк (red.), Sozologia systemowa. Tom IV..., s. 61-76, https://tiny.pl/ gqkds (20.10.2018).

JoHnSON Phillip E., Wielka metafizyczna opowieść nauki (z posłowiem Kazimierza Jodkowskiego), przeł. Piotr Bylica, Archiwum Na Początku..., z. 13, Polskie Towarzystwo Kreacjonistyczne, Warszawa 2003.

Jung Joachim, „Paul K. Feyerabend: Last Interview”, w: Preston, MunÉvar, and Lamb (eds.), The Worst Enemy of Science..., s. 159-168.

KaziBut Radosław, „Potentia absoluta i epistemiczny układ odniesienia Roberta Boyle’a”, Filo-Sofija 2015, vol. 15, nr 30, s. 111-122, https://iny.pl/gzntk (21.10.2018).

Kennedy Donald, Alberts Bruce, Ezell Danine, Goldsmith Tim, Hazen Robert, Lederman Norman, McInerney Joseph, Moore John, Scott Eugenie, Singer Maxine, Smith Mike, Suiter Marilyn, and Wood Rachel (eds.), Teaching About Evolution and the Nature of Science, National Academy Press, Washington, DC. 1999.

KENYON Dean H., „Kreacjonistyczne ujęcie pochodzenia życia”, przeł. Kazimierz Jodkowski, w: JoDKOwsKI, Metodologiczne aspekty..., s. 482-495.

KIERUL Jerzy, Izaak Newton. Bóg, światlo i świat, Oficyna Wydawnicza Quadrivium, Wrocław 1996.

KiLIAn Krzysztof J., „Czym są epistemiczne układy odniesienia?”, Filozoficzne Aspekty Genezy 2017, t. 14, s. 191-236, https://tiny.pl/g8xqp (08.10.2018).

KILIAN Krzysztof J., „Epistemiczne układy odniesienia a problem interteoretycznej niewspółmierności - część 1", Filozoficzne Aspekty Genezy 2017, t. 14, s. 237-280, https://ti ny.pl/gzx3s (08.10.2018).

KILIAN Krzysztof J., „Epistemiczne układy odniesienia a problem interteoretycznej niewspółmierności - część 2", Filozoficzne Aspekty Genezy 2017, t. 14, s. 281-325, https://ti ny.pl/gzx3v (08.10.2018).

KiLian Krzysztof J., „Feyerabend i Lenin a zasada partyjności”, Sofia. Pismo Filozofów Krajów Stowiańskich 2013, nr 13, s. 139-154, https://tiny.pl/gzpdb (20.10.2018).

KILIAN Krzysztof J., „Geneza idei epistemicznych układów odniesienia i ich odmiany”, Filozoficzne Aspekty Genezy 2017, t. 14, s. 137-190, https://tiny.pl/gzx34 (08.10.2018). 
KILIAN Krzysztof J., „O fałszowaniu historii swoich własnych odkryć. Newton i Kant”, w: Dudek i Konstańczak (red.), Homo moralis..., s. 87-95.

Kilian Krzysztof J., Poglądy filozoficzne Paula K. Feyerabenda. Część I. Program metodologiczny, Oficyna Wydawnicza Uniwersytetu Zielonogórskiego, Zielona Góra 2014.

KILIAN Krzysztof J., „Proliferacja jako narzędzie podtrzymujące ewolucję człowieka w świetle poglądów Paula K. Feyerabenda z okresu umiarkowanego", Filozoficzne Aspekty Genezy 2013, t. 13, s. 179-202, https://tiny.pl/xhzd3 (18.10.2018).

Kilian Krzysztof J., „Wzrost wiedzy a zasada tolerancji”, w: Michalczenia, MizińSKa i Ossowska (red.), Poszukiwania filozoficzne. Tom I..., s. 155-173.

KoJonen Erkki V.R., „Methodological Naturalism and the Truth Seeking Objection”, International Journal for Philosophy of Religion 2016, vol. 79, no. 3, s. 1-26, https://tiny.pl/gkf xk (21.10.2018).

Konstańczak Stefan i Turowski Tomasz (red.), Filozofia jako mądrość bycia, Oficyna Wydawnicza Uniwersytetu Zielonogórskiego, Zielona Góra 2009.

Kotersкi Artur, Weryfikacjonistyczne kryteria demarkacji w filozofii nauki Koła Wiedeńskiego, Centrum Nauki Języka Angielskiego Metodą Allana, Akces, Spółka z o.o., Poznań 2002.

KuHn Thomas S., Droga po Strukturze. Eseje filozoficzne z lat 1970-1993 i wywiad-rzeka $\mathbf{z}$ autorem słynnej „Struktury rewolucji naukowych”, wyd. James Conant i John Haugeland, przeł. Stefan Amsterdamski, Wydawnictwo Sic!, Warszawa 2003.

Kunn Thomas S., „Odpowiedź moim krytykom”, w: Kunn, Droga po Strukturze..., s. $117-162$.

Kunn Thomas S., „Postscriptum (1969)”, w: KunN, Struktura rewolucji naukowych..., s. 301-360.

KuHN Thomas S., Struktura rewolucji naukowych, przeł. Helena Ostromęcka i Justyna Nowotniak, Aletheia, Warszawa 2001.

Kunn Thomas S., „The Function of Dogma in Scientific Research”, w: CrombIE (ed.), Scientific Change..., s. 347-369.

LARSON Ronald G., „O argumencie z Boga w lukach wiedzy raz jeszcze”, przeł. Joanna Popek, Filozoficzne Aspekty Genezy 2012, t. 9, s. 199-220, https://tiny.pl/xhzg7 (20.10.2018).

LATAWIEC Anna i Bugajak Grzegorz (red.), Filozoficzne i naukowo-przyrodnicze elementy obrazu świata 7, Wydawnictwo Uniwersytetu Kardynała Stefana Wyszyńskiego, Warszawa 2008 .

Leszczyński Damian (red.), Ewolucja. Filozofia. Religia, Lectiones \& Acroases Philosophicae 2010, vol. 3 . 
Lewontin Richard, „Billions and Billions of Demons”, New York Review of Books 1997, vol. 44, no. 1, https://tiny.pl/gzlb9 (19.10.2018).

Lloyd Steven, „«God of the Gaps»: A Valid Objection?”, Origins 2006, vol. 42, s. 7-10, https://tiny.pl/gzlgr (21.10.2018).

LuKIERSKI Jerzy, „Nauka i religia - czy można pogodzić?”, s. 1-5, https://tiny.pl/gzpd2 (20. 10.2018).

MALEC Grzegorz, „Naturalizm metodologiczny w sporze ewolucjonizmu z kreacjonizmem w świetle poglądów Paula K. Feyerabenda”, Filozoficzne Aspekty Genezy 2012, t. 9, s. 131154, https://tiny.pl/xhzfm (19.10.2018).

Malec Grzegorz, „Teologiczne dylematy Karola Darwina”, Roczniki Filozoficzne 2012, t. 60, nr 1, s. 67-85, http://tiny.pl/g4751 (13.10.2018).

Mączka Janusz i Urbańczyk Piotr (red.), Teologia nauki, Copernicus Center Press, Kraków 2015.

McMuluin Ernan, „Odmiany naturalizmu metodologicznego”, przeł. Ewelina Topolska, Filozoficzne Aspekty Genezy 2012, t. 9, s. 109-129, https://tiny.pl/xh8pf (20.10.2018).

Metallmann Joachim, „Nauka, pogląd na świat, filozofia”, odbitka z Przeglądu Wspótczesnego 1939, nr 5-7, s. 1-49, https://tiny.pl/gzn7n (18.10.2018).

Metallmann Joachim, Zasada ekonomii myślenia. Jej historia i krytyka, E. Wende i Ska, Warszawa, L. Anczyc i S-ka, Kraków 1914.

Meyer Stephen C., „DNA a pochodzenie życia. Informacja, specyfikacja i wyjaśnienie”, przeł. Dariusz Sagan, Filozoficzne Aspekty Genezy 2005/2006, t. 2/3, s. 133-215, https://ti ny.pl/q3mlb (21.10.2018).

Michalczenia Jakub, Mizińska Jadwiga i Ossowska Katarzyna (red.), Poszukiwania filozoficzne. Tom I: Nauka, Prawda. Panu Profesorowi Józefowi Dębowskiemu w darze, Instytut Filozofii Uniwersytetu Warmińsko-Mazurskiego w Olsztynie, Olsztyn 2014.

Mignea Arminius, „Methodological Naturalism and Its Creation Story”, w: Bartlett and Holloway (eds.), Naturalism and Its Alternatives..., s. 129-162.

Miller Keith B., „The Misguided Attack on Methodological Naturalism”, w: SchneIderman and Allmon (eds.), For the Rock Record..., s. 117-140.

Miller Kenneth R., „Odpowiedź na biochemiczny argument z projektu”, przeł. Dariusz Sagan, Filozoficzne Aspekty Genezy 2005/2006, t. 2/3, s. 97-119, https://tiny.pl/qzq81 (21.10. 2018).

MonoD Jacques, Konieczność i przypadek, przeł. Jędrzej Bukowski, Biblioteka Głosu, Warszawa 1979. 
Monton Bradley, Seeking God in Science: An Atheist Defends Intelligent Design, Broadview Press Inc., Toronto 2009.

Munévar Gonzalo (ed.), Beyond Reason: Essays on the Philosophy of Paul K. Feyerabend, Boston Studies in the Philosophy of Science, vol. 132, Kluwer Academic Publishers, Dordrecht — Boston — London 1991.

Musgrave Alan E., „Wpływ Einsteina na filozofię”, przeł. Kazimierz Jodkowski, w: JoDKOWSKI (red.), Na czym polega racjonalność nauki..., s. 79-105.

Nagel Thomas, „Public Education and Intelligent Design”, Philosophy \& Public Affairs 2008, vol. 36, no. 2, s. 209-219, https://tiny.pl/gz5b3 (18.10.2018).

Newton Isaac, Four Letters from Sir Isaac Newton to Doctor Bentley Containing Some Arguments in Proof of a Deity, London 1756, https://tiny.pl/gzlmz (21.10.2018).

Newton Isaac, Matematyczne zasady filozofii przyrody, przeł. Jarosław Wawrzycki, Copernicus Center Press, Kraków 2011.

NiETzSCHE Fryderyk, Jutrzenka. Myśli o przesądach moralnych, Wydawnictwo Zielona Sowa, Kraków 2006.

O'ConNor Robert C., „Nauka przed sądem: analiza racjonalności naturalizmu metodologicznego", przeł. Joanna Popek i Grzegorz Rogula, Filozoficzne Aspekty Genezy 2014, t. 11, s. 95-131, https://tiny.pl/xh8tq (21.10.2018).

O'CONNOR Robert C., ,Science on Trial: Exploring the Rationality of Methodological Naturalism", Perspectives on Science and Christian Faith 1997, vol. 49, s. 15-30, https://tiny.pl/ gzlng (21.10.2018).

OrR H. Allen, „Ponownie darwinizm kontra inteligentny projekt”, przeł. Dariusz Sagan, Filozoficzne Aspekty Genezy 2004, t. 1, s. 33-48, https://iny.pl/gzlkt (21.10.2018).

Parascandalo Renato and Hösle Vittorio, „Three Interviews with Paul K. Feyerabend”, Teleos. A Quarterly Journal of Critical Thought 1995, no. 102, s. 115-148.

Paszewski Andrzej, „Co zdeterminowane, a co przypadkowe w systemach biologicznych — gdzie zaczyna się wolność?”, Nauka 2005, nr 1, s. 53-66, https://tiny.pl/gzj78 (19.10. 2018).

PenNock Robert T., „Bóg w lukach wiedzy: argument z niewiedzy i ograniczenia naturalizmu metodologicznego", przeł. Dariusz Sagan, Filozoficzne Aspekty Genezy 2012, t. 9, s. 155-185, https://tiny.pl/xhnvt (19.10.2018).

Pennock Robert T., Tower of Babel: The Evidence against the New Creationism, MIT Press, Cambridge 1999.

PerAKh Mark, „Nieredukowalna sprzeczność”, przeł. Dariusz Sagan, Filozoficzne Aspekty Genezy 2004, t. 1, s. 71-113, https://tiny.pl/xh8pl (21.10.2018). 
PетRICH Loren, „Artefakty zwierzęce i pozaziemskie - inteligentnie zaprojektowane?”, przeł. Dariusz Sagan, Filozoficzne Aspekty Genezy 2009/2010, t. 6/7, s. 139-153, https://ti ny.pl/xh8hp (21.10.2018).

Pietrzak Zbigniew (red.), Granice nauki, Lectiones \& Acroases Philosophicae 2013, vol. $6, \mathrm{nr} 1$.

PIgludci Massimo, Denying Evolution: Creationism, Scientism and the Nature of Science, Sinauer Associates, Sunderland, Massachusetts 2002.

PIgliucci Massimo, Tales of the Rational: Skeptical Essays About Nature and Science, Freethought Press, Atlanta, Georgia 2000.

PINE Ronald H., „But Some of Them Are Scientists, Aren't They?”, Creation/Evolution 1984, no. 14, s. 6-18, https://tiny.pl/g2vxk (19.10.2018).

Plantinga Alvin, „Naturalizm metodologiczny?”, przeł. Radosław Plato, Filozoficzne Aspekty Genezy 2014, t. 11, s. 37-93, https://tiny.pl/xh89b (19.10.2018).

Plantinga Alvin, „When Faith and Reason Clash: Evolution and the Bible”, Christian Scholar's Review 1991, vol. 21, no. 1, s. 8-33, https://tiny.pl/gzln9 (21.10.2018).

Poе Harry Lee i Мүтүк Chelsea Rose, „Od metody naukowej do naturalizmu metodologicznego. Ewolucja idei”, przeł. Bartosz Błaszczak, Gerard Dmuch, Ewa Komorowska, Iwona Kumiszcze, Izabela Obłaczyńska, Katarzyna Piłka, Radosław Plato, Marika Poprawska, Dariusz Sagan, Karolina Stencel, Katarzyna Szot i Piotr Wróblewski, Filozoficzne Aspekty Genezy 2011, t. 8, s. 137-151, https://tiny.pl/xh8gd (19.10.2018).

Poincaré Henri, Nauka i Hypoteza, przeł. Mieczysław Horwitz, Nakład Jakóba Mortkowicza, Warszawa - Lwów 1908.

Preston John, Munévar Gonzalo, and Lamb David (eds.), The Worst Enemy of Science?: Essays in Memory of Paul Feyerabend, Oxford University Press, New York, Oxford 2000.

Provine William B., „Projekt? Tak! Ale czy inteligentny?”, przeł. Sławomir Piechaczek, Filozoficzne Aspekty Genezy 2005/2006, t. 2/3, s. 217-237, https://tiny.pl/xh8rs (21.10.2018).

ReNNIE John, „15 odpowiedzi na nonsensowne tezy kreacjonistów”, przeł. Karol Sabath, Świat Nauki 2002, nr 9, s. 66-72, https://tiny.pl/gzpws (20.10.2018).

Report of British Association for the Advancement of Science: Report of the NinetySeventh Meeting (Ninety-Ninth Year. South Africa - 1929 July 22 - August 3), London 1930.

Roskal Zenon E., „Eksperyment MacDougalla w epistemicznym układzie odniesienia naturalizmu", w: Bylica, Kilian, Piotrowski i Sagan (red.), Filozofia - nauka - religia..., s. 165-172, http://tiny.pl/g28sj (15.10.2018). 
Russell Colin A., „Views of Nature”, w: Ferngren (ed.), History of Science and Religion..., s. 43-55.

Russell Denise, „Anything Goes”, Social Studies of Science 1983, vol. 13, no. 3, s. 437 464.

SADY Wojciech, „Czego Kazimierz Jodkowski nie dostrzega, jeśli o odkrycia naukowe chodzi?", w: Bylica, Kilian, Piotrowski i Sagan (red.), Filozofia - nauka - religia..., s. 5964, https://tiny.pl/g268h (19.10.2018).

SADY Wojciech, „Dlaczego kreacjonizm «naukowy» nie jest naukowy i dlaczego nie prowadzi do teizmu?", Przeglad Filozoficzny - Nowa Seria 2001, nr 1(37), s. 213-228, http s://tiny.pl/gdw91 (21.10.2018).

SAGAN Dariusz, „Ewaluacja ewolucjonistycznych rozwiązań problemu nieredukowalnej złożoności", Otwarte Referarium Filozoficzne 2009, t. 2, s. 89-116, https://tiny.pl/q3mjg (19.10.2018).

SAGAN Dariusz, „Filtr eksplanacyjny: wykrywanie inteligentnego projektu na gruncie nauk przyrodniczych", Roczniki Filozoficzne 2009, t. 76, nr 1, s. 157-193, https://tiny.pl/q3m15 (19.10.2018).

SAGAN Dariusz, Metodologiczno-filozoficzne aspekty teorii inteligentnego projektu, $\mathrm{Bi}$ blioteka Filozoficznych Aspektów Genezy, t. 6, Instytut Filozofii Uniwersytetu Zielonogórskiego, Zielona Góra 2015, https://tiny.pl/g7m72 (19.10.2018).

SAGAN Dariusz, „Molekularny «zegar Paleya» a darwinowska ewolucja”, Ruch Filozoficzny 2005, t. 67, nr 2, s. 289-304, https://tiny.pl/xh8tk (19.10.2018).

SAGAN Dariusz, „Naturalizm metodologiczny — konieczny warunek naukowości?”, Roczniki Filozoficzne 2013, t. 69, nr 1, s. 73-91, https://tiny.pl/q33sb (19.10.2018).

SAGAN Dariusz, „Naturalizm metodologiczny a zagadnienie prawdy w nauce”, w: ZACHARIASZ (red.), Poznanie a prawda..., s. 167-173, https://tiny.pl/q33sv (18.10.2018).

SAGAN Dariusz, „Problem religijnego charakteru teorii inteligentnego projektu”, Studia Philosophica Wratislaviensia 2011, vol. 6, fasc. 4, s. 55-74, https://tiny.pl/q336q (20.10.2018).

SAGAN Dariusz, „Spór o możliwość wykrywania projektu w naukach przyrodniczych”, Scientia et Fides 2015, vol. 3, nr 1, s. 87-113, https://tiny.pl/gz16f (19.10.2018).

SAGAN Dariusz, „Spór o użyteczność teorii inteligentnego projektu dla nauki”, Kultura i Edukacja 2013, nr 3(96), s. 28-49, https://tiny.pl/xhhg3 (21.10.2018).

SAGAN Dariusz, „Teoria inteligentnego projektu - argumenty za i przeciw”, w: JANECZEK, Starościc, DąBeK i Herda (red.), Filozofia przyrody..., s. 335-383, https://tiny.pl/q336w (13.10.2018). 
SAGAN Dariusz, „Teoria inteligentnego projektu a naukowa debata nad pochodzeniem”, w: Jodkowski (red.), Teoria inteligentnego projektu..., s. 79-122, https://tiny.pl/qzq8f (20. 10.2018).

SAGAN Dariusz, „Zarzut nietestowalności teorii inteligentnego projektu”, Studia Philosophica Wratislaviensia 2013, vol. 8, fasc. 3, s. 43-59, https://tiny.pl/q33s3 (19.10.2018).

Schneiderman Jill S. and Allmon Warren D. (eds.), For the Rock Record: Geologists on Intelligent Design, University of California Press, Berkeley — London 2009.

Sсотт Eugenie C., „Darwin Prosecuted: Review of Johnson's Darwin on Trial”, Creation/ Evolution Journal 1993, vol. 13, no. 2, s. 36-47, https://tiny.pl/g28vq (18.10.2018).

Scotт Eugenie C., Evolution vs. Creationism: An Introduction, 2nd ed., Greenwood Press, Westport, Connecticut, London 2009.

Sellars Wilfrid, „Empiricism and the Philosophy of Mind”, w: Sellars, Science, Perception and Reality..., s. 127-196.

Sellars Wilfrid, Science, Perception and Reality, Ridgeview Publishing Company, Atascadero, California 1991.

ŠEŠELJA Dunja, „Scientific Pluralism and Inconsistency Toleration”, Humana. Mente Journal of Philosophical Studies 2017, vol. 32, s. 1-29, https://tiny.pl/gzjgc (19.10.2018).

Shanks Niall, God, the Devil, and Darwin: A Critique of Intelligent Design Theory, Oxford University Press, New York 2004.

ShaPIRo Robert, Origins. A Skeptic's Guide to the Creation of Life on Earth, Toronto 1987.

SкосzNy Włodzimierz, „Dziedzictwo fizykoteologii we współczesnej myśli chrześcijańskiej”, Zagadnienia Filozoficzne w Nauce 1991, vol. 13, s. 79-85, https://tiny.pl/gzlm6 (21. 10.2018).

Skoog Gerald, Cielen Randy, Jordan Linda, Lariviere Janis, Scharmann Larry, and Scott Eugenie, „A NSTA (National Science Teachers Association) Position Statement on the Teaching of Evolution", w: Kennedy, Alberts, Ezell, Goldsmith, Hazen, Lederman, McInerney, Moore, Scott, Singer, Smith, Suiter, and Wood (eds.), Teaching About Evolution..., s. 124-126, https://tiny.pl/gzj6m (20.10.2018).

SOBER Elliott, „Teoria inteligentnego projektu a nadnaturalizm — o tezie, że projektantem może być Bóg lub istoty pozaziemskie", przeł. Sławomir Piechaczek, Filozoficzne Aspekty Genezy 2007/2008, t. 6/7, s. 21-39, https://tiny.pl/xhn85 (19.10.2018).

„Sprawozdanie z dyskusji o nauczaniu etyki w szkołach wyższych”, Etyka 1966, nr 1, s. 134-136, https://tiny.pl/gzj71 (19.10.2018). 
Stilwell Phil, „The Status of Methodological Naturalism as Justified by Precedent”, Studies in Liberal Arts and Sciences 2009, no. 41, s. 229-247, https://tiny.pl/gzjsx (20.10.2018).

Strahler Arthur N., Understanding Science: An Introduction to Concepts and Issues, Buffalo, New York 1992.

ThoRNHILl Richard, „Historyczny związek między darwinizmem a argumentem z biologicznego projektu", przeł. Anna Droś, Natalia Górska, Mateusz Krzyżanowski, Renata Merda, Zofia Sadowska i Dariusz Sagan, Filozoficzne Aspekty Genezy 2012, t. 9, s. 79-105, https:// tiny.pl/gzlnb (21.10.2018).

Todd Scott C., „A View from Kansas on That Evolution Debate”, Nature 1999, no. 6752, s. 423, https://tiny.pl/gz5bs (18.10.2018).

VAN DER MeER Jitse M., „Przekonania towarzyszące, ideologia i nauka”, przeł. Dariusz Sagan, Filozoficzne Aspekty Genezy 2016, t. 13, s. 153-194, https://tiny.pl/gzjrs (19.10.2018).

Vihalemm Rein, „The Kuhn-Loss Thesis and the Case of Phlogiston Theory”, Science Studies 2000 , vol. 13 , no. 1 , s. $68-78$.

Wartofsky Marx W., „How to Be a Good Realist”, w: Munévar (ed.), Beyond Reason..., s. $25-40$

Watson David M.S., „Adaptation”, w: Report of British Association for the Advancement of Science..., s. 88-99, https://tiny.pl/gzpfk (20.10.2018).

Weinberg Steven, Sen o teorii ostatecznej, przeł. Piotr Amsterdamski, Alkazar, Warszawa 1994.

WeINER January, „Hipotezy o powstaniu i wczesnej ewolucji życia. Historia dociekań (od Darwina do Millera)", Kosmos 2009, t. 58, nr 3-4, s. 501-528, https://tiny.pl/gzpdr (20.10. 2018).

WOODWARD Thomas, „Istota sporu darwinizmu z teorią inteligentnego projektu: przyrodnicza symfonia makroewolucji”, przeł. Dariusz Sagan, Filozoficzne Aspekty Genezy 2007/ 2008, t. 6/7, s. 7-20, https://tiny.pl/xhnkv (21.10.2018).

WróBlewski Andrzej K., „Posłowie”, w: Newton, Matematyczne zasady..., s. 715-722.

ZавоєотмY Andrzej, „Naturalizm metodologiczny w nauce — dylemat teisty”, Filozoficzne Aspekty Genezy 2016, t. 13, s. 25-48, https://tiny.pl/gzp1f(20.10.2018).

Zachariasz Andrzej L. (red.), Poznanie a prawda, Wydawnictwo Uniwersytetu Rzeszowskiego, Rzeszów 2009.

Zachariasz Andrzej L. (red.), Profile racjonalności, Wydawnictwo UMCS, Lublin 1988.

Życı́́sKi Józef, „Ewolucyjna wizja przyrody a XIX-wieczny teizm”, Studia Philosophiae Christianae 1996, t. 32, nr 1, s. 73-98, https://tiny.pl/gzjr1 (19.10.2018). 


\section{Argumenty na rzecz naturalizmu jako epistemicznego układu odniesienia}

\section{Streszczenie}

Artykuł bada ważniejsze argumenty na rzecz naturalizmu metodologicznego. Analizy te pozwalają uznać tezę, w myśl której nie istnieją dobre powody do uznania naturalizmu metodologicznego za kamień węgielny współczesnej nauki. Ani znane fakty, ani rozumowania nie stanowią nieodpartych racji na rzecz tego naturalizmu.

Slowa kluczowe: epistemiczne układy odniesienia, naturalizm, nadnaturalizm, artyficjalizm, naturalizm metodologiczny, warunek Jodkowskiego.

\section{Arguments for Naturalism as an Epistemic Framework}

\section{Summary}

This paper investigates putatively plausible arguments for methodological naturalism. The analysis sets out to show that there are no good reasons for accepting methodological naturalism as a cornerstone of contemporary science. Neither any known fact, nor any line of reasoning, provides an irrefutable rationale for such a form of naturalism.

Keywords: epistemic frameworks, naturalism, supernaturalism, artificialism, methodological naturalism, Jodkowski's condition. 